\title{
Unemployment, Education and Skills Constraints in Post-Apartheid South Africa
}

\author{
Rosa Dias \\ Dorrit Posel \\ Department of Economics \\ University of KwaZulu-Natal \\ diasr@ukzn.ac.za \\ posel@ukzn.ac.za
}

Development Policy Research Unit

DPRU Working Paper 07/120

ISBN: 978-1-920055-42-4

March 2007 


\section{Abstract}

This paper investigates the relationship between education and unemployment in postapartheid South Africa, and probes the argument that employment growth has been inhibited particularly by skills constraints. We use probit regression analysis to show that higher education protected against unemployment in both 1995 and 2003, and that overall, the relative benefits to tertiary education rose over the period. We show also that these aggregate trends mask substantial variation among race groups and within race groups, among men and women. However, after taking into account changes in the survey instruments used to measure employment, we find only modest evidence of skills-intensive employment growth. Rather, the increase in formally qualified labour was considerably larger than the increase in demand for skilled and semi-skilled labour over the period, and so unemployment rates even among graduates increased over the period.

\section{Acknowledgement}

This paper was prepared for presentation at the DPRU Conference on "Accelerated and Shared Growth in South Africa: Determinants, Constraints and Opportunities", October 2006.

Development Policy Research Unit Tel: +2721 6505705

Fax: +2721650 5711
Information about our Working Papers and other published titles are available on our website at: http://www.commerce.uct.ac.za/dprul 


\section{Table of Contents}

Introduction...............................................................................1

1. Education and Employment Status: A Review...................3

2. Trends in Education and Employment, 1995 - 2003..........6

2.1 Educational Attainment of the Working-age Population.........6

2.2 Education and Labour Force Participation............................8

2.3 Estimating the Probability of Being Unemployed..................10

3. Labour Demand and Skills Shortages.............................19

3.1 Changes in the Skills Composition of Employment.............19

3.2 Other Constraints to Employment Growth - Perceptions of the Unemployed and of Employers.......................................21

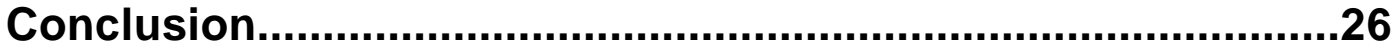

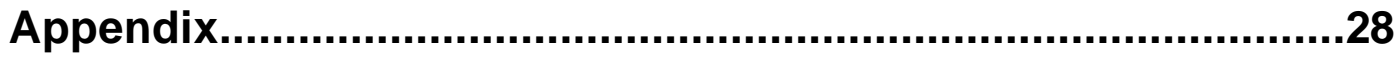

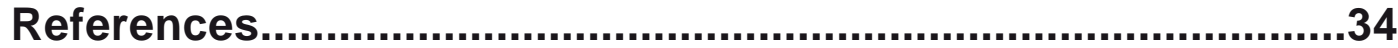




\section{Introduction}

The objective of this paper is to interrogate the relationship between education and unemployment and to consider how and why this relationship has changed since the political transition in South Africa.

Several studies have analysed the role of education in affecting labour market outcomes in South Africa (cf. Schultz and Mwabu 1998, Bhorat and Leibbrandt 2001, Hosking 2001, Cichello et al 2003, van der Berg and Burger 2003). In earlier work, this research focussed on the relationship between education and the earnings of the employed. Formal education was found to be a strong and significant predictor of income earned. Data collected during the early years of the democratic transition in South Africa also indicated a premium on matric (or grade 12) education (Schultz \& Mwabu 1998).

More recently, economists have begun to explore the role of education in affecting another labour market outcome - the probability of gaining or finding employment (Bhorat 2004, Kingdon and Knight 2005, Moleke 2006). This relationship has particular relevance in South Africa which has been characterised by very high and rising rates of unemployment in the post-apartheid period. Perhaps the most commonly cited cause of unemployment in the country is that following skills-biased economic growth, a skills "mismatch" exists between the supply of and demand for labour (cf. Bhorat and Hodge 1999, Poswell 2002, Bhorat 2004, Cassim 2006, Naidoo 2006). Concerns with skills shortages have been embraced in national policy, evidenced by the recent launching of the Joint Initiative on Priority Skills Acquisition. If South Africa is indeed confronted with a "chronic skills shortage", then we might anticipate education to have become an increasingly important predictor of employment status in the country. The findings of recent studies that document rising rates of unemployment among graduates in the country, therefore, have been surprising.

This paper seeks to contribute to research on education and unemployment in two ways: first by showing that changes in the protection afforded by higher education in South Africa differ strongly by race and by gender; and second by 'refocusing' attention on demand-side considerations in the labour market. The primary data that we use for the study come from two nationally representative household surveys - the 1995 October Household Survey (OHS) and the September 2003 Labour Force Survey (LFS 2003: 2). 
In the first section of the paper, we review current research on the relationship between education and unemployment. In section 2, we revisit trends in education and unemployment in the country. We show descriptively that the working-age population in South Africa has become more educated: compared to 1995, in 2003 a larger proportion particularly of younger Africans reported that they had at least matric education. We also demonstrate that unemployment rates in the South African labour market decrease with educational attainment. Probit analysis, however, reveals that although education protects against unemployment, this effect is not monotonically increasing in education, and that a discontinuity exists at matric education. Furthermore, we find that the relative benefits of higher education in securing employment did increase over the period but only among particular groups of South Africans.

In 2003, the relative benefits of higher education for both Coloureds and Indians increased considerably, whereas they either remained unchanged or declined for Africans and Whites. Further disaggregation reveals that aggregate trends among Africans and Whites also mask divergent changes by gender. Relative to those with less education, African men with at least matric education, and White men with post-matric education, were significantly more likely to find employment over the period. Among African and White women, however, the relative benefits of matric and post-matric qualifications declined considerably. The relationship between education and unemployment in South Africa, therefore, is not only racially differentiated but also highly gendered.

In the final empirical section of the paper we revisit changes in labour demand in the country. We show that although the demand for skilled labour experienced the largest relative increase from 1995, this was from a small base, and in absolute terms, growth in skilled employment was comparable to that in "unskilled" (or less skilled) employment. The demand for semi-skilled labour grew the most in absolute terms, but we demonstrate that a significant portion of this rise derives from changes in how employment has been defined over the period. The skills-bias of employment growth, although evident, is modest and we suggest that concerns with the quality of labour supplied should not overshadow other reasons for low employment growth over the period. Responses by employers in firm-based surveys underscore the importance of recognising other constraints (such as "crime and theft", "currency volatility" and "corruption in government") that inhibit employment expansion (Chandra and Nganou 2001, Devey et al 2005), and that would help account for why, even among graduates, unemployment rates have risen. To the extent that skills significantly inhibit (future) employment expansion, we suggest that perhaps the most pervasive skill absent among the unemployed is their lack of previous work experience. 


\section{Education and Employment Status: A Review}

There are a number of reasons why we would expect the probability of employment generally to be rising in education. Among prospective employees, human capital may directly increase productivity making individuals with greater human capital more valuable. An employer, therefore, would rather hire someone with more, than less, education. Even where higher formal education does not directly increase an individual's productivity, employers with imperfect information about prospective employees may use education as a "sorting device" to help evaluate the future worth of an employee. The amount and type of schooling may signal a future employee's capacity to learn and can be used to predict how quickly an individual will acquire skills on the job, how productive the individual will be after training, the individual's work ethic and his or her commitment to the job.

Analogously, among the prospective self-employed, individuals with more schooling may be in a better position to start their own business. They would have greater literacy and numerical skills, and may be more able to overcome credit and other barriers to entry in self-employment.

We would expect the relationship between education and unemployment also to be influenced by market forces: in labour markets where the demand for skilled labour increases, for example, the relative benefits of higher education should rise. This would seem to be particularly apposite for the South African labour market. One of the frequently cited explanations offered for sustained and rising unemployment in the country concerns the lack of skills of the labour force. ${ }^{1}$ These skills shortages are attributed to a shift in the composition of labour demand towards skilled labour, in the context of the inherited educational disparities and backlogs of apartheid.

Among the first to document a change in the skills composition of labour demand in South Africa were Bhorat and Hodge (1999). Using data from 1970 to 1995, these authors identified positive employment effects for skilled workers and negative effects for unskilled workers, driven particularly by changes in production methods in domestic firms. Subsequent data from 1995 to 2002 suggested that the trend towards skilled employment had continued in post-apartheid South Africa. However, in the same article that Bhorat identified "skills-biased employment shifts" using data from the 1995 October Household

1 See, for example, the Business Opinion, "SA suffering from chronic skills mismatch" (The Sunday Times, 29 January 2006); "Lack of skills is a danger to SA's gains" (The Business Report, The Natal Mercury, 16 November 2005). 
Survey (OHS) and the 2002 (February) Labour Force Survey (LFS), he also noted the puzzling finding of rising unemployment rates among graduates (Bhorat 2004). Bhorat identified this trend as being driven particularly by growing joblessness among African graduates.

Research undertaken by Moleke (2006) and the Human Sciences Research Council for the period 1990 to 1998 also identified racial differences in graduate unemployment. The study, based on a postal survey which gathered evidence of the employment experiences of about 2700 university graduates in South Africa, found that Whites were significantly more likely to have gained employment after graduating and Africans and Coloureds, the least likely. ${ }^{2}$

Both studies by Bhorat (2004) and Moleke (2006) observe that employment rates among graduates were influenced by field of specialisation. Bhorat, for example, shows that in 2002, among those with degrees, the largest proportions of the unemployed were qualified in Education, Training and Development and in Business, Commerce and Management Studies. Moleke finds that individuals whose field of study was Law or the Humanities and Arts were least likely to find employment immediately after graduating. Moleke suggests further that the employment experiences of graduates were also influenced by whether individuals had graduated from historically black universities.

These findings offer some explanation for the puzzle of rising unemployment rates among graduates in the context of skills shortages in the economy. Individuals may not be specialising in the fields of study required by employers, and employers may evaluate the quality of tertiary education very differently across institutions. Concerns with the quality of formal education (van der Berg and Burger 2003, Umalusi 2004) have also been used to explain rising rates of unemployment among matriculants. ${ }^{3}$

In their review of unemployment in South Africa, Kingdon and Knight (2005) explore changes in the relationship between education and unemployment more formally with binary probit analysis of the 1995 OHS and the 2003 (September) LFS data. Using an aggregate sample of all broad labour force participants, they estimated the probability that an individual would be unemployed in each year. They could then identify and compare the marginal effects of a range of individual characteristics including age and

$2 \quad$ It is possible that these findings have a selection bias if whites who do not find employment are more likely than other South Africans to migrate aboard.

3 See, for example, "It's official: Matric is easier" (The Mail and Guardian, 1 October 2004). 
education, on this probability, thereby capturing "ceteris paribus changes in the incidence of unemployment over time" (Kingdon and Knight, 2005: 14).

Kingdon and Knight found that relative to those who had no education, labour force participants with "primary", "junior" or "secondary" education were more likely to have been unemployed in 2003 than in 1995. They also found that the relative benefits of "higher" education had fallen, but by considerably less, leading them to conclude that "those possessing higher education have been largely insulated from these unemployment increases" (2005: 14). Kingdon and Knight, however, did not explore how the relationship between education and the probability of employment by race or gender had changed over the period.

This paper contributes to the literature on unemployment by showing that aggregate relationships between education and employment, and aggregate changes over time, differ markedly by race, and within race groups, among men and women. We also revisit the puzzle of rising unemployment rates among the more educated by reconsidering changes in the skills composition of labour demand and the view that unemployment in the country is sustained through skills constraints. 


\section{Trends in Education and Employment, 1995 - 2003}

\subsection{Educational Attainment of the Working-Age Population}

Differential access to education across race groups was one of the defining features of apartheid South Africa, entrenching large inter-racial differences in economic status. With the political transition, a clear objective of the ANC government has been to reduce racial inequalities in educational access, increasing particularly educational attainment among Africans.

Information on educational attainment captured in the nationally representative household surveys suggests that educational levels increased over the last decade. ${ }^{4}$ Table 1 summarises educational attainment by age cohort, for the total working-age population, and for Africans specifically, from 1995 to 2003. In 2003, most South Africans of working-age had not matriculated (just over 30 per cent had). But from 1995 to 2003, the percentage of all working-age South Africans with at least a matric education had risen by four percentage points. ${ }^{5}$

\footnotetext{
$4 \quad$ There is a concern that educational attainment is inflated by respondents in these national household surveys and in the Population Census (see, for example, Simkins 2001). However, there is no obvious reason to suspect that the extent of overstating would have increased between 1995 and 2003.

This reported increase in matric qualifications amongst the working-age population is credible and is consistent with data provided by the Department of Education (2005). Note that matric enrolments increased from 1995 but then declined from 1999 following changes in education policy regarding age eligibility in formal schooling. However, from 1995 to 2003, the matric pass rate increased by about 37 per cent.
} 
Table 1: Matric (Grade 12) and Tertiary Education by Age Cohort, 1995 and 2003

\begin{tabular}{|c|c|c|c|c|}
\hline & \multicolumn{2}{|c|}{ All working-age South Africans } & \multicolumn{2}{|c|}{ Working-age Africans } \\
\hline Proportion, with & 1995 & 2003 & 1995 & 2003 \\
\hline \multicolumn{5}{|l|}{ All $16-65$ years } \\
\hline Matric & $\begin{array}{l}17.88 \\
(0.033)\end{array}$ & $\begin{array}{l}21.24 \\
(0.003)\end{array}$ & $\begin{array}{l}13.66 \\
(0.003)\end{array}$ & $\begin{array}{l}17.42 \\
(0.003)\end{array}$ \\
\hline \multirow[t]{2}{*}{ Tertiary education } & 8.34 & & 5.57 & 5.60 \\
\hline & $(0.028)$ & $(0.003)$ & $(0.003)$ & $(0.003)$ \\
\hline \multicolumn{5}{|l|}{ Age cohorts } \\
\hline \multirow{2}{*}{$\begin{array}{l}16-20 \text { years } \\
\text { Matric }\end{array}$} & & & & \\
\hline & $\begin{array}{l}12.81 \\
(0.004)\end{array}$ & $\begin{array}{l}11.35 \\
(0.005)\end{array}$ & $\begin{array}{l}9.36 \\
(0.004)\end{array}$ & $\begin{array}{l}8.16 \\
(0.004)\end{array}$ \\
\hline \multirow[t]{2}{*}{ Tertiary education } & 1.38 & 0.57 & 1.06 & 0.38 \\
\hline & $(0.002)$ & $(0.001)$ & $(0.002)$ & $(0.0001)$ \\
\hline $\begin{array}{l}21-25 \text { years } \\
\text { Matric }\end{array}$ & $\begin{array}{l}29.54 \\
(0.007)\end{array}$ & $\begin{array}{l}33.78 \\
(0.007)\end{array}$ & $\begin{array}{l}25.61 \\
(0.007)\end{array}$ & $\begin{array}{l}30.45 \\
(0.008)\end{array}$ \\
\hline Tertiary education & $\begin{array}{l}8.04 \\
(0.004)\end{array}$ & $\begin{array}{l}6.49 \\
(0.004)\end{array}$ & $\begin{array}{l}5.79 \\
(0.004)\end{array}$ & $\begin{array}{l}4.78 \\
(0.003)\end{array}$ \\
\hline \multirow{2}{*}{$\begin{array}{l}26-35 \text { years } \\
\text { Matric }\end{array}$} & & & & \\
\hline & $\begin{array}{l}22.78 \\
(0.005)\end{array}$ & $\begin{array}{l}30.97 \\
(0.006)\end{array}$ & $\begin{array}{l}19.26 \\
(0.006)\end{array}$ & $\begin{array}{l}28.29 \\
(0.006)\end{array}$ \\
\hline Tertiary education & 12.13 & 13.43 & 9.45 & 9.29 \\
\hline \multirow{2}{*}{$\begin{array}{l}36-45 \text { years } \\
\text { Matric }\end{array}$} & & & & \\
\hline & $\begin{array}{l}13.65 \\
(0.005)\end{array}$ & $\begin{array}{l}17.53 \\
(0.005)\end{array}$ & $\begin{array}{l}8.48 \\
(0.004)\end{array}$ & $\begin{array}{l}12.91 \\
(0.005)\end{array}$ \\
\hline Tertiary education & $\begin{array}{l}10.71 \\
(0.005)\end{array}$ & $\begin{array}{l}13.06 \\
(0.006)\end{array}$ & $\begin{array}{l}6.72 \\
(0.005)\end{array}$ & $\begin{array}{l}7.72 \\
(0.005)\end{array}$ \\
\hline \multirow{2}{*}{$\begin{array}{l}46-55 \text { years } \\
\text { Matric }\end{array}$} & & & & \\
\hline & 10.83 & 11.31 & 3.71 & 5.08 \\
\hline \multirow[t]{2}{*}{ Tertiary education } & $\begin{array}{l}(0.005) \\
8.55\end{array}$ & $\begin{array}{l}(0.000) \\
10.85\end{array}$ & 3.64 & 5.74 \\
\hline & $(0.005)$ & $(0.005)$ & $(0.003)$ & $(0.004)$ \\
\hline \multirow{2}{*}{$\begin{array}{l}56-65 \text { years } \\
\text { Matric }\end{array}$} & & & & \\
\hline & $\begin{array}{l}8.32 \\
(0.005)\end{array}$ & $\begin{array}{l}10.04 \\
(0.007)\end{array}$ & $\begin{array}{l}1.87 \\
(0.002)\end{array}$ & $\begin{array}{l}2.70 \\
(0.003)\end{array}$ \\
\hline \multirow[t]{2}{*}{ Tertiary education } & 6.19 & 8.81 & 2.51 & 2.42 \\
\hline & $(0.005)$ & $(0.006)$ & $(0.003)$ & $(0.003)$ \\
\hline
\end{tabular}

Source: OHS 1995 and LFS 2003: 2

Notes: $\quad$ Standard errors are in parentheses. The data are weighted using the population weights released by Statistics South Africa (Stats SA) in September 2005. 
Rising educational attainment occurred particularly among younger cohorts. The percentage of all adults with matric, and with some tertiary, education is significantly higher among younger, than older, adults. In 1995, for example, 35 per cent of all individuals in the 26-35 year cohort were reported with matric education or higher, compared to only about twenty per cent of all adults in the 46-55 cohort. Furthermore, educational qualifications particularly among younger South Africans increased over the period. In 2003 , about 44 per cent of all individuals aged 26 to 35 years were reported as having at least matric education.

Not surprisingly, given the legacy of apartheid, educational attainment remains lower among Africans on average. But there is evidence of significant increases over the period, particularly in the proportion of younger Africans who are reported as having completed their matric year.

\subsection{Education and Labour Force Participation}

The increase in educational attainment among working-age South Africans is reflected in a more educated labour force. Table 2 describes the share of the employed and the unemployed, by level of formal education, for 1995 and 2003. By 2003, a significantly smaller proportion of both the employed and the unemployed were reported as having no, or only primary, education and a significantly larger share were reported with at least a matric education. For example, in 1995, about 22 per cent of the employed and 19 per cent of the unemployed had (only) matriculated; by 2003, this had increased to 27 per cent and 25 per cent respectively. 
Table 2: Share of the Labour Force by Educational Attainment, 1995 and 2003

\begin{tabular}{|l|l|l||l|l|}
\hline & \multicolumn{2}{|c||}{1995} & \multicolumn{2}{c|}{2003} \\
\hline & Employed & Unemployed & Employed & Unemployed \\
\hline No education & 0.081 & $0.096^{* *}$ & 0.056 & $0.047^{* *}$ \\
Primary & $(0.003)$ & $(0.005)$ & $(0.002)$ & $(0.002)$ \\
& 0.229 & $0.306^{*}$ & 0.210 & $0.245^{\star *}$ \\
Incomplete secondary & $(0.005)$ & $(0.007)$ & $(0.005)$ & $(0.004)$ \\
& 0.322 & $0.390^{*}$ & 0.300 & $0.423^{*}$ \\
Matric & $(0.005)$ & $(0.007)$ & $(0.005)$ & $(0.005)$ \\
& 0.224 & $0.187^{*}$ & 0.270 & $0.249^{* *}$ \\
Tertiary & $(0.005)$ & $(0.006)$ & $(0.005)$ & $(0.005)$ \\
& 0.143 & $0.021^{*}$ & 0.159 & $0.031^{*}$ \\
& $(0.005)$ & $(0.002)$ & $(0.006)$ & $(0.002)$ \\
\hline \multicolumn{1}{|c|}{$\mathrm{N}$} & & & & \\
\hline
\end{tabular}

Source: OHS 1995 and LFS 2003: 2

Notes: 1 . The data are weighted using the population weights released by Stats SA in September 2005.

2. Standard errors in parentheses. * Means for the employed and the unemployed are significantly different at the 1 per cent level, or ** at the 5 per cent level. 3. Shares may not add up to 1 because of rounding.

Overall, the unemployed had lower levels of education than the employed. But over the period, these educational differences became far less pronounced, indicating that the share of the unemployed with higher levels of education increased by more than it did among the employed. (For a more comprehensive table describing differences between the employed and the unemployed, see Table 12 in the Appendix. ${ }^{6}$ )

In Table 3, we summarise the employment status of individuals by their level of education. Employment rates are clearly higher among the more educated. However, from 1995 to 2003 , employment rates decreased across all educational groupings of the labour force, including those with tertiary education. Employment rates declined the most (and, therefore, unemployment rates increased the most) among individuals with some secondary, or with a matric, education.

Falling employment rates across all levels of educational attainment coincided with increased search activity among the unemployed. Amongst the unemployed, search rates are positively related to educational attainment, and this became more pronounced over the period, as search rates increased the most among those with more education.

$6 \quad$ On average, in both 1995 and 2003, the unemployed were more likely than the employed to be: aged 16 to 25 years; African; female; not married; living in a larger household; in a rural area; and resident in a household where social transfers were received. 
Table 3: Employment Status and Education among the Economically Active

\begin{tabular}{|l|l|l|l||l|l|l|}
\hline & \multicolumn{3}{|c||}{1995} & \multicolumn{2}{c|}{ 2003 } \\
\hline $\begin{array}{l}\text { Employment } \\
\text { status (\%) } \\
\text { by education }\end{array}$ & Employed & $\begin{array}{l}\text { Searching } \\
\text { unemployed }\end{array}$ & $\begin{array}{l}\text { Non- } \\
\text { searching } \\
\text { unemployed }\end{array}$ & Employed & $\begin{array}{l}\text { Searching } \\
\text { unemployed }\end{array}$ & $\begin{array}{l}\text { Non- } \\
\text { searching } \\
\text { unemployed }\end{array}$ \\
\hline None & 66.99 & 11.73 & 21.29 & 61.75 & 14.67 & 23.58 \\
$(0.13)$ & $(0.01)$ & $(0.01)$ & $(0.014)$ & $(0.01)$ & $(0.012)$ \\
\hline Primary & 64.37 & 15.73 & 19.91 & 53.70 & 21.55 & 24.75 \\
& $(0.01)$ & $(0.01)$ & $(0.01)$ & $(0.008)$ & $(0.006)$ & $(0.007)$ \\
\hline Secondary & 66.55 & 17.20 & 16.24 & 48.95 & 27.26 & 23.79 \\
& $(0.01)$ & $(0.01)$ & $(0.01)$ & $(0.007)$ & $(0.006)$ & $(0.006)$ \\
\hline Matric & 74.20 & 14.76 & 11.05 & 59.44 & 25.03 & 15.53 \\
& $(0.01)$ & $(0.01)$ & $(0.01)$ & $(0.009)$ & $(0.007)$ & $(0.006)$ \\
\hline Tertiary & 94.19 & 3.97 & 1.84 & 87.33 & 9.51 & 3.16 \\
& $(0.004)$ & $(0.004)$ & $(0.003)$ & $(0.007)$ & $(0.006)$ & $(0.003)$ \\
\hline $\begin{array}{l}\text { Average } \\
\text { years of } \\
\text { education }\end{array}$ & 9.00 & 8.42 & 7.37 & 9.55 & 9.30 & 8.32 \\
& $(0.06)$ & $(0.08)$ & $(0.09)$ & $(0.06)$ & $(0.05)$ & $(0.06)$ \\
\hline
\end{tabular}

Source: OHS 1995 and LFS 2003: 2

Notes: $\quad 1$. Standard errors in parentheses.

2. The mean years of education is derived from the responses to a question relating to the highest level of education achieved. In the OHS 1995 this question (Q2.16) does not distinguish the educational levels of those individuals who passed grades 1 to 3 . Consequently all these individuals have been assigned three years of education. However, the distinction is possible in the LFS 2003 data. Consequently, mean years of education in 1995 may be biased upward.

We explore our descriptive findings on the relationship between education and unemployment, and how this has changed over time, more comprehensively through a series of probit regressions that isolate the effects of educational attainment on employment status.

\subsection{Estimating the Probability of Being Unemployed}

We estimate among all labour force participants (aged 16 to 65 years), the probability that an individual will be unemployed (whether searching for employment or not) rather than employed. We use probit regressions for 1995 and 2003 similar to those estimated by Kingdon and Knight (2005), but with some differences in the set of explanatory variables. We differentiate incomplete secondary, matric education and post-matric or tertiary education (rather than only "secondary" and "higher" education), and we introduce household-level characteristics (household size and whether the household receives a social pension), found to be significant in distinguishing the employed and the unemployed. 
Table 4 reports the estimated coefficients from the conditional probit regressions for 1995 and 2003 , as well as the marginal effects. The omitted categories in the estimations are all economically active individuals who are 16 to 20 years of age, White, have primary school education and live in Gauteng.

Controlling for a range of individual characteristics of labour force participants, including their age, gender, race and marital status, as well as household characteristics, the estimations show that education protects against unemployment. Overall, individuals with higher education had a significantly lower probability of being unemployed. For example, in 1995, labour force participants with tertiary education on average were twenty per cent less likely than otherwise identical individuals but with only primary education, to be unemployed. However, the effect is not monotonically increasing in education levels. Rather, the benefits of higher education in securing employment only 'kick in' when labour force participants have at least matric education.

From 1995 to 2003, however, we find that for the whole sample of labour force participants, the advantages of matric education did not change, and that the relative benefits of incomplete secondary education fell slightly (by about 1.3 percentage points). In contrast, the relative benefits of tertiary education in protecting against unemployment grew by almost five percentage points. Although unemployment rates rose among those with tertiary education, these labour force participants became even less likely than those with only primary education to be unemployed. The data, therefore, suggest the 'ratcheting-up' of the formal educational content of new employment in the country.

These aggregate changes, however, reflect divergent trends among race groups. In Table 5 , we report the results from re-estimating the probit regressions for racially disaggregated samples. The table includes only the estimated coefficients and marginal effects for the education variables for 1995 and 2003 (results for the full estimations are available in Table 13 in the Appendix). We show the results for a combined sample of Coloureds and Indians because this increases the sample size needed for the analysis, and the separate estimations indicated matching trends across these groups. 
Table 4: Probability of Unemployment, 1995 and 2003

\begin{tabular}{|c|c|c|c|c|c|c|}
\hline & & \multicolumn{2}{|c|}{1995} & \multicolumn{2}{|c|}{2003} & \multirow[b]{2}{*}{$\begin{array}{c}\text { Difference in } \\
\text { marginal effects } \\
(2003-1995) * 100\end{array}$} \\
\hline $\begin{array}{l}1= \\
0=\end{array}$ & $\begin{array}{l}\text { unemployed } \\
\text { employed }\end{array}$ & Coefficient & $\begin{array}{l}\text { Marginal } \\
\text { effects }\end{array}$ & Coefficient & $\begin{array}{l}\text { Marginal } \\
\text { effects }\end{array}$ & \\
\hline 21 & 25 years & $\begin{array}{l}-0.281^{*} \\
(0.036)\end{array}$ & -0.075 & $\begin{array}{l}-0.283^{*} \\
(0.041)\end{array}$ & -0.106 & -3.1 \\
\hline 26 & 35 years & $\begin{array}{l}-0.664^{*} \\
(0.036)\end{array}$ & -0.177 & $\begin{array}{l}-0.754^{*} \\
(0.041)\end{array}$ & -0.274 & -9.7 \\
\hline 36 & 45 years & $\begin{array}{l}-0.944^{*} \\
(0.040)\end{array}$ & -0.224 & $\begin{array}{l}-1.103^{*} \\
(0.042)\end{array}$ & -0.360 & -13.6 \\
\hline 46 & 55 years & $\begin{array}{l}-1.104^{*} \\
(0.045)\end{array}$ & -0.210 & $\begin{array}{l}-1.287^{*} \\
(0.045)\end{array}$ & -0.378 & -16.8 \\
\hline 56 & 65 years & $\begin{array}{l}-1.230^{*} \\
(0.066)\end{array}$ & -0.205 & $\begin{array}{l}-1.411^{*} \\
(0.638)\end{array}$ & -0.365 & -16.0 \\
\hline Fen & tale & $\begin{array}{l}0.405^{\star} \\
(0.019)\end{array}$ & 0.120 & $\begin{array}{l}0.321^{*} \\
(0.019)\end{array}$ & 0.123 & 3.0 \\
\hline Afric & & $\begin{array}{c}0.906^{*} \\
(0.049)^{*}\end{array}$ & 0.226 & $\begin{array}{l}0.852^{*} \\
(0.047)\end{array}$ & 0.294 & 6.8 \\
\hline Colc & oured & $\begin{array}{l}0.349^{*} \\
(0.059)\end{array}$ & 0.112 & $\begin{array}{l}0.361^{*} \\
(0.063)\end{array}$ & 0.142 & 3.0 \\
\hline Indi & & $\begin{array}{l}0.281^{*} \\
(0.082)\end{array}$ & 0.090 & $\begin{array}{l}0.256^{*} \\
(0.078)\end{array}$ & 0.101 & 1.1 \\
\hline Mar & ried & $\begin{array}{l}-0.383^{*} \\
(0.021)\end{array}$ & -0.111 & $\begin{array}{l}-0.282^{\star} \\
(0.021)\end{array}$ & -0.108 & 0.3 \\
\hline Urb & an dweller & $\begin{array}{l}0.122^{*} \\
(0.029)\end{array}$ & 0.035 & $\begin{array}{l}0.086^{*} \\
(0.027)\end{array}$ & 0.033 & -0.2 \\
\hline No & schooling & $\begin{array}{c}0.020 \\
(0.035)\end{array}$ & 0.006 & $\begin{array}{c}0.036 \\
(0.042)\end{array}$ & 0.014 & 0.8 \\
\hline Inco & mplete secondary & $\begin{array}{c}0.007 \\
(0.024)\end{array}$ & 0.002 & $\begin{array}{c}0.040^{* * *} \\
(0.022)\end{array}$ & 0.015 & 1.3 \\
\hline Mat & & $\begin{array}{l}-0.218^{*} \\
(0.032)\end{array}$ & -0.060 & $\begin{array}{l}-0.157^{*} \\
(0.028)\end{array}$ & -0.060 & 0.0 \\
\hline Tert & iary & $\begin{array}{l}-0.983^{*} \\
(0.054)\end{array}$ & -0.200 & $\begin{array}{l}-0.739^{*} \\
(0.044)\end{array}$ & -0.248 & -4.8 \\
\hline Hou & sehold size & $\begin{array}{l}0.070^{*} \\
(0.004)\end{array}$ & 0.020 & $\begin{array}{l}0.077^{*} \\
(0.005)\end{array}$ & 0.030 & 1.0 \\
\hline Soc & ial transfer receipt & $\begin{array}{l}0.330^{*} \\
(0.029)\end{array}$ & 0.144 & $\begin{array}{l}0.349^{\star} \\
(0.023)\end{array}$ & 0.136 & -0.8 \\
\hline
\end{tabular}

Source: OHS 1995 and LFS 2003: 2

Notes: Omitted categories are Whites, aged 16 to 20 years, with primary school education, living in rural areas. The regression also included 9 provincial dummy variables not reported here. Standard errors are in parentheses. * Significant at the 1 per cent level ${ }^{* *}$ Significant at the 5 per cent level

*** Significant at the 10 per cent level. 
The positive relationship between education and employment strengthened most consistently for Coloureds and Indians over the period. As education among these labour force participants rose, so they became increasingly less likely than those with only primary education to be unemployed. By 2003 , the probability of unemployment among Indians and Coloureds ${ }^{7}$ with tertiary and matric education had fallen by about 13 and 10 percentage points respectively (relative to those with only primary education).

Table 5: Probability of Unemployment by Race, 1995 and 2003

\begin{tabular}{|c|c|c|c|c|c|}
\hline & \multicolumn{2}{|c|}{1995} & \multicolumn{2}{|c|}{2003} & \multirow[b]{2}{*}{$\begin{array}{c}\text { Difference in } \\
\text { marginal effects } \\
(2003-1995) * 100\end{array}$} \\
\hline $\begin{array}{l}1=\text { unemployed } \\
0=\text { employed }\end{array}$ & Coefficient & $\begin{array}{c}\text { Marginal } \\
\text { effects }\end{array}$ & Coefficient & $\begin{array}{c}\text { Marginal } \\
\text { effects }\end{array}$ & \\
\hline \multicolumn{6}{|l|}{ Coloureds + Indians } \\
\hline No schooling & $\begin{array}{c}0.014 \\
(0.101)\end{array}$ & 0.003 & $\begin{array}{c}0.057 \\
(0.175)\end{array}$ & 0.018 & 1.5 \\
\hline Incomplete secondary & $\begin{array}{l}-0.003 \\
(0.054)\end{array}$ & -0.001 & $\begin{array}{l}-0.096 \\
(0.062)\end{array}$ & -0.029 & -2.8 \\
\hline Matric & $\begin{array}{l}-0.437^{*} \\
(0.070)\end{array}$ & -0.077 & $\begin{array}{l}-0.650^{*} \\
(0.078)\end{array}$ & -0.176 & -9.9 \\
\hline Tertiary & $\begin{array}{l}-0.667^{*} \\
(0.113)\end{array}$ & -0.098 & $\begin{array}{l}-1.081^{*} \\
(0.129)\end{array}$ & -0.226 & -12.8 \\
\hline \multicolumn{6}{|l|}{ Africans } \\
\hline No schooling & $\begin{array}{c}0.027 \\
(0.037)\end{array}$ & 0.009 & $\begin{array}{c}0.064 \\
(0.044)\end{array}$ & 0.026 & 1.7 \\
\hline Incomplete secondary & $\begin{array}{l}-0.027 \\
(0.027)\end{array}$ & -0.009 & $\begin{array}{c}0.017 \\
(0.024)\end{array}$ & 0.007 & 1.6 \\
\hline Matric & $\begin{array}{l}-0.167^{*} \\
(0.037)\end{array}$ & -0.056 & $\begin{array}{l}-0.110^{*} \\
(0.030)\end{array}$ & -0.044 & 1.2 \\
\hline Tertiary & $\begin{array}{l}-1.168^{*} \\
(0.068)\end{array}$ & -0.279 & $\begin{array}{l}-0.791^{*} \\
(0.049)\end{array}$ & -0.282 & -0.3 \\
\hline \multicolumn{6}{|l|}{ Whites } \\
\hline No schooling & $\begin{array}{l}-0.178 \\
(0.933)\end{array}$ & -0.028 & -- & -- & \\
\hline Incomplete secondary & $\begin{array}{l}-0.378 \\
(0.440)\end{array}$ & -0.061 & $\begin{array}{c}0.111 \\
(0.402)\end{array}$ & 0.024 & 8.5 \\
\hline Matric & $\begin{array}{l}-0.873^{* *} \\
(0.447)\end{array}$ & -0.111 & $\begin{array}{l}-0.280 \\
(0.401)\end{array}$ & -0.057 & 5.4 \\
\hline Tertiary & $\begin{array}{l}-1.151^{*} \\
(0.445)\end{array}$ & -0.111 & $\begin{array}{l}-0.655^{\star \star *} \\
(0.408)\end{array}$ & -0.105 & 0.6 \\
\hline
\end{tabular}

Source: OHS 1995 and LFS 2003: 2

Notes: Standard errors are in parentheses. * Significant at the 1 per cent level ** Significant at the 5 per cent level ${ }^{* *}$ Significant at the 10 per cent level.

$7 \quad$ These findings are consistent with those reported in the study by Hoogeveen and Özler (2004) of increased economic well-being among Coloureds over the period (based on the Income and Expenditure Surveys from 1995 and 2000). 
Among Whites and among Africans, our findings are quite different. In 2003, Whites remained significantly less likely than other South Africans to be unemployed (Table 4). But over the period, Whites gained no extra protection against unemployment through higher education. Rather among Whites, the benefits particularly of matric education declined (by more than five percentage points). Africans with at least matric education also faced significantly lower probabilities of unemployment than otherwise identical Africans with only primary education. However, by 2003 , the relative benefits of matric education had declined slightly while those of tertiary education were unchanged.

These overall trends among Africans and Whites also comprise contrasting experiences for men and women over the period. In a final set of estimations, we further disaggregated our samples by gender. These results are reported in Tables 6 and 7 (again only for the education explanatory variables). (See Tables 14 and 15 in the Appendix for the full set of estimated coefficients.) 
Table 6: Probability of Unemployment among Men, 1995 and 2003

\begin{tabular}{|c|c|c|c|c|c|}
\hline & \multicolumn{2}{|c|}{1995} & \multicolumn{2}{|c|}{2003} & \multirow[b]{2}{*}{$\begin{array}{c}\text { Difference in } \\
\text { marginal effects } \\
(2003-1995) * 100\end{array}$} \\
\hline $\begin{array}{l}1=\text { unemployed } \\
0=\text { employed }\end{array}$ & Coefficient & $\begin{array}{l}\text { Marginal } \\
\text { effects }\end{array}$ & Coefficient & $\begin{array}{l}\text { Marginal } \\
\text { effects }\end{array}$ & \\
\hline \multicolumn{6}{|l|}{ Coloureds + Indians } \\
\hline No schooling & $\begin{array}{l}-0.012 \\
(0.156)\end{array}$ & -0.002 & $\begin{array}{l}-0.158 \\
(0.252)\end{array}$ & -0.040 & -3.8 \\
\hline Incomplete secondary & $\begin{array}{c}0.124 \\
(0.070)\end{array}$ & 0.021 & $\begin{array}{l}-0.053 \\
(0.093)\end{array}$ & -0.014 & -3.5 \\
\hline Matric & $\begin{array}{l}-0.356 \\
(0.091)\end{array}$ & -0.051 & $\begin{array}{l}-0.445 \\
(0.107)\end{array}$ & -0.110 & -5.9 \\
\hline Tertiary & $\begin{array}{l}-0.417 \\
(0.157) \\
\end{array}$ & -0.055 & $\begin{array}{l}-0.784 \\
(0.190) \\
\end{array}$ & -0.156 & -10.1 \\
\hline \multicolumn{6}{|l|}{ Africans } \\
\hline No schooling & $\begin{array}{l}-0.065 \\
(0.052)\end{array}$ & -0.019 & $\begin{array}{c}0.016 \\
(0.067)\end{array}$ & 0.006 & 2.5 \\
\hline Incomplete secondary & $\begin{array}{c}0.039 \\
(0.037)\end{array}$ & -0.011 & $\begin{array}{l}-0.014 \\
(0.034)\end{array}$ & -0.005 & 0.6 \\
\hline Matric & $\begin{array}{l}-0.133^{*} \\
(0.049)\end{array}$ & -0.038 & $\begin{array}{l}-0.141^{*} \\
(0.044)\end{array}$ & -0.053 & -1.5 \\
\hline Tertiary & $\begin{array}{l}-0.940^{*} \\
(0.095)\end{array}$ & -0.196 & $\begin{array}{l}-0.641^{*} \\
(0.071)\end{array}$ & -0.218 & -2.2 \\
\hline \multicolumn{6}{|l|}{ Whites } \\
\hline No schooling & $\begin{array}{l}-0.734 \\
(1.093)\end{array}$ & -0.048 & -- & -- & \\
\hline Incomplete secondary & $\begin{array}{l}-0.653 \\
(0.637)\end{array}$ & -0.062 & $\begin{array}{l}-0.079 \\
(0.538)\end{array}$ & -0.012 & 5.0 \\
\hline Matric & $\begin{array}{c}-1.173^{\star *} \\
(0.660)\end{array}$ & -0.079 & $\begin{array}{l}-0.448 \\
(0.538)\end{array}$ & -0.060 & 1.9 \\
\hline Tertiary & $\begin{array}{l}-1.513^{*} \\
(0.647)\end{array}$ & -0.071 & $\begin{array}{c}-0.857^{* * *} \\
(0.550)\end{array}$ & -0.084 & -1.3 \\
\hline
\end{tabular}

Source: OHS 1995 and LFS 2003: 2

Notes: Standard errors are in parentheses. * Significant at the 1 per cent level ** Significant at the 5 per cent level *** Significant at the 10 per cent level.

From 1995 to 2003, Coloured and Indian men and women both realised large increases in the relative benefits of matric and tertiary education. For example, on average, women with tertiary education in this group were fifteen percentage points less likely to be unemployed in 2003 than in 1995 (relative to women with only primary education), and for men with tertiary education, the change in the marginal effect was over ten per cent.

African men with matric and particularly tertiary education faced reduced chances of unemployment over the period, as did White men with tertiary education, although the changes are more modest. However, African women and particularly White women with at least matric education experienced significant increases in the probability of unemployment (relative to the respective base categories). The relative benefits of 
matric education in securing employment among White and African women, for example, declined by ten and four percentage points respectively.

Table 7: Probability of Unemployment among Women, 1995 and 2003

\begin{tabular}{|c|c|c|c|c|c|}
\hline & \multicolumn{2}{|c|}{1995} & \multicolumn{2}{|c|}{2003} & \multirow[b]{2}{*}{$\begin{array}{l}\text { Difference in } \\
\text { marginal effects } \\
(2003-1995) * 100\end{array}$} \\
\hline $\begin{array}{l}1=\text { unemployed } \\
0=\text { employed }\end{array}$ & Coefficient & $\begin{array}{l}\text { Marginal } \\
\text { effects }\end{array}$ & Coefficient & $\begin{array}{c}\text { Marginal } \\
\text { effects }\end{array}$ & \\
\hline \multicolumn{6}{|l|}{ Coloureds + Indians } \\
\hline No schooling & $\begin{array}{c}0.086 \\
(0.129)\end{array}$ & 0.022 & $\begin{array}{c}0.245 \\
(0.239)\end{array}$ & 0.087 & 6.5 \\
\hline Incomplete secondary & $\begin{array}{l}-0.106 \\
(0.075)\end{array}$ & -0.026 & $\begin{array}{l}-0.109 \\
(0.088)\end{array}$ & -0.036 & -1.0 \\
\hline Matric & $\begin{array}{l}-0.515^{*} \\
(0.099)\end{array}$ & -0.109 & $\begin{array}{l}-0.829^{*} \\
(0.113)\end{array}$ & -0.242 & -13.3 \\
\hline Tertiary & $\begin{array}{l}-0.900 \\
(0.150)\end{array}$ & -0.151 & $\begin{array}{l}-1.391^{*} \\
(0.173)\end{array}$ & -0.299 & -14.8 \\
\hline \multicolumn{6}{|l|}{ Africans } \\
\hline No schooling & $\begin{array}{l}0.112^{*} \\
(0.048)\end{array}$ & 0.043 & $\begin{array}{l}0.102^{\star * *} \\
(0.057)\end{array}$ & 0.040 & -0.3 \\
\hline Incomplete secondary & $\begin{array}{l}0.007 \\
(0.036)\end{array}$ & 0.003 & $\begin{array}{c}0.044 \\
(0.035)\end{array}$ & 0.018 & 1.5 \\
\hline Matric & $\begin{array}{l}-0.179^{*} \\
(0.052)\end{array}$ & -0.067 & $\begin{array}{l}-0.088^{* *} \\
(0.042)\end{array}$ & -0.035 & 3.2 \\
\hline Tertiary & $\begin{array}{l}-1.330^{*} \\
(0.081)\end{array}$ & -0.372 & $\begin{array}{l}-0.873^{*} \\
(0.061)\end{array}$ & -0.326 & 4.6 \\
\hline \multicolumn{6}{|l|}{ Whites } \\
\hline No schooling & -- & -- & -- & -- & -- \\
\hline Incomplete secondary & $\begin{array}{l}-0.188 \\
(0.438)\end{array}$ & -0.042 & $\begin{array}{c}0.313 \\
(0.301)\end{array}$ & 0.082 & 12.4 \\
\hline Matric & $\begin{array}{l}-0.681 \\
(0.436)\end{array}$ & -0.128 & $\begin{array}{l}-0.115 \\
(0.307)\end{array}$ & -0.028 & 10.0 \\
\hline Tertiary & $\begin{array}{c}-0.912^{* *} \\
(0.443)\end{array}$ & -0.142 & $\begin{array}{c}-0.493^{* * *} \\
(0.314)\end{array}$ & -0.1001 & 4.2 \\
\hline
\end{tabular}

Source: OHS 1995 and LFS 2003: 2

Notes: Standard errors are in parentheses. * Significant at the 1 per cent level ** Significant at the 5 per cent level *** Significant at the 10 per cent level.

What accounts for these different experiences between men and women, and among groups of women in the labour market? One possibility that has been highlighted in the South African literature concerns the area of study of graduates. We explore this further in Table 8, which describes the distribution of economically active graduates, and unemployment rates, by field of study. This information is not collected in the $1995 \mathrm{OHS}$, and so we cannot investigate distributional shifts over the period. 
Table 8: Distribution of the Economically Active, and Unemployment Rates, by Field of Study, 2003

\begin{tabular}{|c|c|c|c|c|}
\hline \multirow[b]{2}{*}{ Field of study } & \multicolumn{3}{|c|}{ Distribution of the economically active } & \multirow[b]{2}{*}{$\begin{array}{l}\text { Unemployment } \\
\text { rate by field of } \\
\text { study }\end{array}$} \\
\hline & Women & Men & $\begin{array}{l}\text { Coloured \& } \\
\text { Indian } \\
\text { women }\end{array}$ & \\
\hline Communication studies, languages & 3.28 & 2.01 & 1.61 & 18.95 \\
\hline Education, training, development & 34.15 & 19.18 & 32.38 & 9.90 \\
\hline Manufacturing, engineering, technology & 3.42 & 19.02 & 3.98 & 14.46 \\
\hline Human and social sciences & 5.02 & 3.13 & 3.82 & 15.85 \\
\hline Law, military studies, security & 3.81 & 8.72 & 2.17 & 5.00 \\
\hline Health and social services & 14.66 & 6.89 & 20.07 & 6.83 \\
\hline Agriculture and nature conservation & 0.72 & 4.20 & 0.40 & 7.15 \\
\hline Culture and arts & 2.57 & 1.63 & 1.76 & 14.60 \\
\hline Business, commerce, management studies & 23.16 & 24.28 & 24.54 & 15.71 \\
\hline Physical, mathematical, computer, life studies & 6.98 & 6.92 & 7.44 & 24.13 \\
\hline Services & 2.12 & 2.50 & 1.54 & 7.29 \\
\hline \multirow[t]{2}{*}{ Physical planning, construction } & 0.11 & 1.51 & 0.24 & 9.37 \\
\hline & 100.00 & 100.00 & 100.00 & \\
\hline
\end{tabular}

Source: LFS 2003: 2

Note: $\quad$ Percentages may not add up to 100 per cent because of rounding.

In 2003, there is some evidence that male graduates were concentrated in fields of study for which unemployment rates were lower. In particular, more than twice as many men than women reported qualifying in "law, military studies and security" where unemployment rates were only five per cent. Men were also less likely to have specialised in the fields of "communication and languages" and the "human sciences" with higher unemployment rates (of 19 and 16 per cent respectively). There is also some indication that relative to all women, Coloured and Indian women graduated in areas with greater labour absorption - notably in the "health and social sciences". However, the differences are neither large nor consistent enough between men and women, and amongst women, to explain convincingly the results reported earlier. ${ }^{8}$

Another possible explanation is that Coloured and Indian women, in particular, have benefited from the ways in which firms have responded to employment equity initiatives. We do not consider this further here and rather flag this as an area for future research.

In summary, in this section we have documented rising levels of education of the labour

8 For example, men were considerably more likely than women to have specialised in "manufacturing, engineering and technology", an area of study associated with comparatively high unemployment rates. Coloured and Indian women were more likely than other women to have graduated in the field of commerce, where unemployment rates are also relatively high. 
force from 1995 to 2003. We have shown that overall the relative protection against unemployment afforded by matric education did not change. Those with tertiary qualifications on average faced a further reduced probability of unemployment compared to those with only primary education, although these aggregate trends comprise divergent experiences among race groups and among men and women. We have shown also that although the more educated received relatively more protection, they were not insulated from unemployment increases, and unemployment rates even among graduates rose considerably over the period. In the next section we complement these findings on the relationship between education and unemployment with a consideration of changes on the demand-side of the labour market. 


\section{Labour Demand and Skills Shortages}

The view that South Africa faces a 'chronic' skills shortage is underpinned by the argument that economic growth has been strongly biased towards more highly skilled employment and a mismatch, therefore, exists between the skills-requirements of labour demand and the qualifications of labour supply. We revisit this argument here by first investigating changes in the skills composition of employment.

\subsection{Changes in the Skills Composition of Employment}

From 1995 to 2003, measured employment in South Africa increased by approximately 1.8 million 'jobs' (see Table 2, and Casale and Posel, 2006). In Table 9, the change in employment is disaggregated according to its skills classification (given by the International Standard Classification of Occupations (ISCO)). ${ }^{9,10}$

Over the period, the biggest absolute expansion (of almost one million) in employment occurred in work classified as semi-skilled. Furthermore, the largest percentage increase (about 64 per cent) derived from that in skilled employment. An initial reading of the data, therefore, supports the argument of a shift towards more skilled employment in the economy. However, there are a number of caveats that must be made when interpreting these data.

First, employment classified by skills level is undercounted in 1995 because of a much larger number of missing data for occupational and sectoral variables of the employed in 1995 than in 2003 (Casale and Posel, 2006). This explains why deriving the total change

9 Occupational codes are post-coded based on the respondent's description of the type of work performed. Translating the type of employment into an occupational code may introduce error in the classification of employment. Nevertheless, we are using the same data and classifications as those analysed by others to motivate skills-biased growth.

10 Skilled labour is identified by codes 1 and 2 of the ISCO and refers to legislators, senior officials, managers and professionals. Semi-skilled labour is identified by codes 3 to 8 , representing technical and associate professionals, skilled agriculture and fishery workers, craft and related trade workers, and plant and machine operators and assemblers. Unskilled labour is identified by ISCO code 9, and represents employment in elementary occupations, including paid domestic work. Note that the ISCO-88 guidelines (1993:6) recognise significant skill level differences among those with code 1, and particularly among managers. We have classified all individuals within this group as skilled, thereby providing an upper bound on skilled employment in the country. In 1995 there were 497085 (1 662 unweighted) legislators, senior officials and managers; in 2003, this had increased significantly to 816389 (1545 unweighted) individuals. 
in employment by aggregating changes across skills levels yields a greater increase (of about 200 000) than simply deriving the change in total (undifferentiated) employment. The change in employment measured by skills level, therefore, is over-estimated in Table 9 , but because the missing observations are widely distributed by the age, gender and education of the employed, it is difficult to ascertain whether one category of skills is likely to be particularly affected.

Table 9: The Change in Employment in SA, 1995 and 2003

\begin{tabular}{|l|c|c|}
\hline \multirow{2}{*}{ Total employment } & \multicolumn{2}{|c|}{ South Africa, 1995 -2003 } \\
\cline { 2 - 3 } -skilled & Absolute $\triangle$ in employment & \% change \\
\cline { 2 - 3 } -semi-skilled & 528439 & 63.8 \\
-unskilled & 958944 & 17.0 \\
Agriculture & 465760 & 15.8 \\
-skilled & 47822 & 650.9 \\
-semi-skilled & 230060 & 83.2 \\
-unskilled & -313176 & -32.7 \\
Employment (excluding self & & \\
employment) & & \\
-skilled & 357775 & 63.18 \\
-semi-skilled & 221596 & 4.17 \\
-unskilled & 31121 & 1.10 \\
\hline
\end{tabular}

Source: OHS 1995 and LFS 2003: 2

Second, recorded skilled employment increased dramatically but from a low base, and the absolute rise in unskilled employment was comparable to that in skilled employment. Consequently, while the share of skilled work in total employment grew (from about 9 to 12 per cent), the share of unskilled work fell only slightly (from about 31 to 30 per cent). Although unskilled employment declined in the mining, manufacturing and agricultural sectors, it increased in the retail, construction and finance sectors. (See Table 16 in the Appendix for absolute and relative changes in employment levels disaggregated by skills classification and sector.)

Third, most of the increase in employment (about two-thirds) derived from the growth in self-employment, and particularly in work classified as unskilled or semi-skilled. An expansion of self-employment, and especially survivalist activity, is not surprising given conditions of high unemployment. However, we need to recognise also that this type of employment is likely to have been particularly affected by changes and improvements in data capture over the period. Key among the changes was the explicit inclusion of 
subsistence farming as employment in the Labour Force Surveys (Posel and Casale, 2001). In 1995, there were no subsistence farmers recorded in the October Household Survey; in 2003, approximately 220000 subsistence farmers were included in employment estimates. According to ISCO conventions, subsistence farming is classified as semiskilled (self) employment. Its inclusion in 2003 , therefore, accounts for a considerable part of the increase in semi-skilled self-employment, and thus of the increase in semi-skilled employment overall.

Fourth, Table 9 shows that the shift to more skilled labour derived principally from changes in wage employment, where the growth in skilled work accounted for most of the employment increase. But even so, the demand for unskilled labour did not fall absolutely, and as a share of total wage employment, it declined by only one percentage point, from 32 to 31 per cent. (See Table 17 in the Appendix for absolute and relative changes in wage employment levels disaggregated by skills classification and sector.) Furthermore, the increase in the demand for skilled labour appears small compared to the increase in the supply of more educated labour over the period. Although particular industries and sectors may have faced specific skills shortages, it is, therefore, difficult to see evidence of 'massive' shortages in wage employment at a macro level. Of course, questions can be raised about the quality of formal education and the accuracy of reporting on educational qualifications. But we suggest also that questions should be raised, other than about the quality of labour supplied, about why labour demand has grown so slowly over the eightyear period.

\subsection{Other Constraints to Employment Growth - Perceptions of the Unemployed and of Employers}

With the introduction of the Labour Force Surveys in South Africa, more probing questions about unemployment were included in the survey instrument. One such question concerns how the unemployed account for their joblessness. ${ }^{11}$ A number of possible reasons were provided, including that the individual lacked the "skills or qualifications for available jobs", that the individual could not "find any work" and more specifically, could not find "suitable work" in terms of the salary, location or conditions of the employment. Table 10 summarises these responses in the September LFS 2003 for all the unemployed (broadly defined), and for the sub-samples with matric and tertiary education.

11 The September 2003 LFS asks of the unemployed: "Why did ... not work during the past seven days?" (Question 3.1, p. 11) 
In 2003 , only about 10 per cent of all the unemployed attributed their joblessness to a lack of skills or qualifications for the jobs that were available. The percentage declines as the educational qualifications of the unemployed increase, with less than two per cent of those with tertiary education identifying skills as a barrier to employment.

There are obvious reporting biases that are likely to occur here. People may be unwilling to recognise that they are not adequately trained for positions. Furthermore, labour force participants may know less about the availability of jobs for which they would not adequately be trained. However, it is reassuring that individuals with more education are less likely to report that their lack of skills inhibits their employment access. It must also be significant that the overwhelming majority, even among those with tertiary education, attribute their unemployment to not being able to find any work. ${ }^{12}$

Table 10: Reasons for not working, as a Percentage of the Unemployed, 2003

\begin{tabular}{|l|c|c|c|}
\hline Reasons identified in the LFS 2003:2 & $\begin{array}{c}\text { \% of all the } \\
\text { unemployed }\end{array}$ & $\begin{array}{c}\text { \% unemployed } \\
\text { with matric } \\
\text { education }\end{array}$ & $\begin{array}{c}\text { \% unemployed } \\
\text { with tertiary } \\
\text { education }\end{array}$ \\
\hline $\begin{array}{l}\text { Starting a job at a definite date in the } \\
\text { future }\end{array}$ & 0.3 & 0.6 & 1.2 \\
\hline Too young or too old to work & 0.3 & 0.0 & 0.0 \\
\hline Seasonal worker & 0.7 & 0.4 & $\mathbf{1 . 7}$ \\
\hline $\begin{array}{l}\text { Lack of skills or qualifications for } \\
\text { available jobs }\end{array}$ & $\mathbf{9 . 8}$ & $\mathbf{7 . 2}$ & $\mathbf{6 3 . 2}$ \\
\hline $\begin{array}{l}\text { Cannot find any work } \\
\text { Cannot find suitable work (salary, } \\
\text { location of work, conditions not } \\
\text { satisfactory) }\end{array}$ & $\mathbf{7 6 . 2}$ & $\mathbf{7 8 . 3}$ & $\mathbf{2 0 . 4}$ \\
\hline $\begin{array}{l}\text { Contract worker (e.g. mineworker resting } \\
\text { according to contract) }\end{array}$ & 0.2 & $\mathbf{6 . 0}$ & 0.0 \\
\hline Retrenched & 2.0 & 0.4 & 3.7 \\
\hline Other & 5.5 & 1.6 & 9.8 \\
\hline
\end{tabular}

Source: LFS 2003: 2

Note: $\quad$ The unemployed include both the searching and the non-searching unemployed.

12 A very small percentage (about five per cent) of the unemployed explains their joblessness by their not being able to find 'suitable' work. The percentage was significantly higher among those with tertiary education, a finding that would be consistent with the more educated having higher aspirations or being more 'choosy' than those with less education. 
The Labour Force Survey, like all household surveys, does not collect comparable information from the perspective of employers, and to our knowledge there are no national databases containing comprehensive information on firms' employment and production decisions. In recent years, however, the World Bank has undertaken surveys of (particularly large-scale) firms in the Greater Johannesburg and Durban Metropolitan Areas (the GJMA and GDMA respectively) in an attempt to discern the major constraints to growth (Chandra and Nganou 2001, Devey et al 2005). ${ }^{13}$

In both surveys, managers and CEOs of firms were asked to identify constraints to expansion from a given list of possible concerns. The list was not identical across the surveys, with a notable exception in the GJMA firm survey being the exclusion of HIV/ AIDs as a constraint. Nonetheless, there are very strong overlaps in the responses given by firms. In both surveys, "crime and theft" was identified as the major constraint to growth: in the GJMA survey, firms "unanimously" marked this as the leading constraint (Chandra and Nganou, 2001: 8); in the GDMA survey, about 83 per cent of firms identified this as an obstacle to expansion. Furthermore, "currency volatility" (or "depreciation of the rand") and "corruption in government" were highlighted as among the four leading constraints in both surveys (Chandra and Nganou 2001, Devey et al 2005).

Firms also identified "skills shortages" or the "availability of technical and vocational skills" as a constraint - this was ranked sixth and fifth in the GDMA and GJMA surveys respectively and appeared to be more of a concern in large firms (Devey et al 2005: 56 ), and firms involved in information and technology (Chandra and Nganou 2001: 8). However, there is little evidence of extensive shortages of skills leading to sustained vacancies in firms. In the GDMA survey, firms identified a very limited number of particularly senior management and professional positions that they found difficult to fill. Moreover, the overwhelming majority (80 per cent) of firms reported that they were not training workers because they were already "sufficiently trained" or further training was "not relevant because of the nature of work" (Devey et al 2005: 69). In the GJMA survey, "between 20 - 30 per cent of (IT) firms carried over vacant positions from 1998 to 1999" (Chandra and Nganou 2001:18), but there is no information provided on the number of vacancies.

13 In the GJMA, approximately 1235 formal sector and 500 informal sector firms across all industries were surveyed in 1998, and in the GDMA, 600 firms were surveyed from 2002 to 2003 (Chandra and Nganou 2001, Devey et al 2005). 
We find the responses by firms on their recruitment processes to be particularly instructive in understanding "skills shortages" in the country. Firms in both surveys expressed a strong preference for hiring individuals with previous work experience. In the GDMA survey well over 80 per cent of firms hired individuals with previous work experience. A considerably smaller number of firms (almost 33 per cent) hired individuals with relevant work experience. This might suggest that firms face difficulties in hiring individuals with work experience relevant to their particular sector and operations, but nevertheless value some sort of prior work experience above none. This clearly spells poorer labour market opportunities for younger individuals entering the labour market, a point that is consistent with results presented earlier and below in the paper. Relevant work experience, however, is not a skill typically that can be acquired through formal education.

Less than one per cent of firms in the GDMA study hired workers with tertiary education only whereas almost 8 per cent of firms recruited graduates with work experience. Over 32 per cent of firms employed individuals with both secondary education and work experience compared to less than 14 per cent of firms who were willing to hire individuals with secondary schooling but no prior work experience. The value placed on work experience in addition to formal education is evident. Although educational institutions can extend the practical training components of certain programmes, work experience ultimately requires employment. This point is clearly highlighted in the results of the GDMA survey where vocational training was perceived to be a "poor substitute for prior relevant work experience" (Devey et al, 2005: 57).

In Table 11, we describe the work experience of the unemployed captured in the September LFS 2003. That about 65 per cent of all the unemployed, 74 per cent of those with matric education, and 59 per cent of those with tertiary education, were reported as never having worked before, is perhaps the most convincing evidence of a significant skills crisis in the country. But this must be understood surely as being as much an effect of sustained unemployment, as its cause. 
Table 11: Work Experience of the Unemployed, 2003

\begin{tabular}{|l|c|c|c|}
\hline $\begin{array}{l}\text { Proportion with } \\
\text { previous work } \\
\text { experience among: }\end{array}$ & All the unemployed & $\begin{array}{l}\text { Unemployed with } \\
\text { matric education }\end{array}$ & $\begin{array}{l}\text { Unemployed with } \\
\text { tertiary education }\end{array}$ \\
\hline All the unemployed & 0.354 & 0.262 & 0.409 \\
& $(0.006)$ & $(0.009)$ & $(0.024)$ \\
\hline Unemployed aged 21- & 0.179 & 0.159 & 0.231 \\
25 years & $(0.007)$ & $(0.013)$ & $(0.039)$ \\
\hline
\end{tabular}

Source: LFS 2003: 2

Note: Standard errors in parentheses 


\section{Conclusion}

Reasons for high and rising unemployment in South Africa have most often been sought on the supply-side of the labour market. One explanation is that labour is not sufficiently qualified for new employment that is, or could be, created and that a skills shortage is inhibiting further employment growth. Concerns that South Africa is experiencing skills shortages are easily motivated given the legacy of apartheid - in terms of both the unequal spending on education and the effects of the anti-apartheid struggle on the accumulation of human capital. Reports of a "brain drain" from South Africa over the last decade would provide further explanation for why the supply of skilled labour cannot meet the demands for this labour, particularly if the economy is moving along a "high-skilled" employment growth path.

In this paper, we investigated skills constraints to employment growth by first interrogating the relationship between formal education and unemployment and how this relationship changed from 1995 to 2003. Using binary probit analysis, we showed that the probability of unemployment among the economically active in South Africa was reduced as education increased, but that this effect was only significant if a labour force participant had completed at least matric (or grade 12) education. The relative benefits to matric education remained unchanged over the period, but relative to an individual with only primary school education, individuals with tertiary education, on average, were more protected against unemployment over the period. However, we found also that these aggregate trends masked substantial variation among race groups and within race groups, among men and women. Among Coloured and Indian men, and particularly women, the relative benefits of higher education increased significantly and considerably. Among Africans and Whites, the aggregate trends were less marked because the relative benefits of higher education among African and White women declined over the period.

To provide more context for our probit results, we probed a bit further changes in labour demand in South Africa over the period. We showed that the increase in skilled and semi-skilled employment had been considerably less than the increase in the supply of labour with matric and tertiary education. This explains why although on average, the more educated were relatively less likely than those with only primary education to be unemployed over the period, they were not insulated from growing unemployment. Unemployment rates among those with matric and tertiary education increased by about fourteen and seven percentage points respectively. 
It is possible that prospective labour force participants are not specialising in specific fields of study required by the labour market or that employers have concerns about the quality of formal education. It may also be that hiring preferences among employers contribute to experiences of skills shortages. But we have suggested that perhaps the most obvious skill lacking in the South African labour force is the absence of work experience. The majority of the unemployed in the country has never worked before. This, in turn, underscores the importance of focusing on factors, in addition to the quality of labour supplied, that inhibit an increase in the demand for labour. Recent surveys of large-scale firms in two greater metropolitan areas in South Africa yielded almost the identical ranking among firms of their three main constraints to expansion - crime and theft, corruption, and currency volatility. More research needs to be undertaken also on the constraints of smaller firms, across a range of sectors, and we need more discussion on the ways in which labour demand in the country can be stimulated. 


\section{Appendix}

Table 12: Individual and Household-Level Characteristics of the Employed and the Unemployed, 1995 and 2003 (mean (standard error))

\begin{tabular}{|c|c|c|c|c|}
\hline & \multicolumn{2}{|c|}{1995} & \multicolumn{2}{|c|}{2003} \\
\hline & Employed & Unemployed & Employed & Unemployed \\
\hline Individual characteristics & & & & \\
\hline Age 16 - 20 years & $\begin{array}{l}0.031 \\
(0.001)\end{array}$ & $\begin{array}{l}0.102^{*} \\
(0.004)\end{array}$ & $\begin{array}{l}0.027 \\
(0.001)\end{array}$ & $\begin{array}{l}0.126^{*} \\
(0.003)\end{array}$ \\
\hline Age 21 - 25 years & $\begin{array}{l}0.121 \\
(0.003)\end{array}$ & $\begin{array}{l}0.258^{*} \\
(0.005)\end{array}$ & $\begin{array}{l}0.109 \\
(0.003)\end{array}$ & $\begin{array}{l}0.282^{*} \\
(0.004)\end{array}$ \\
\hline Age $26 \quad 35$ years & $\begin{array}{l}0.355 \\
(0.004)\end{array}$ & $\begin{array}{l}0.378^{* *} \\
(0.005)\end{array}$ & $\begin{array}{l}0.351 \\
(0.005)\end{array}$ & $\begin{array}{l}0.348 \\
(0.005)\end{array}$ \\
\hline Age $36 \quad 45$ years & $\begin{array}{l}0.290 \\
(0.004)\end{array}$ & $\begin{array}{l}0.173^{*} \\
(0.004)\end{array}$ & $\begin{array}{l}0.272 \\
(0.004)\end{array}$ & $\begin{array}{l}0.148^{*} \\
(0.003)\end{array}$ \\
\hline Age $46 \quad 55$ years & $\begin{array}{l}0.153 \\
(0.003)\end{array}$ & $\begin{array}{l}0.074^{*} \\
(0.003)\end{array}$ & $\begin{array}{l}0.176 \\
(0.003)\end{array}$ & $\begin{array}{l}0.073^{*} \\
(0.002)\end{array}$ \\
\hline Age $56 \quad 65$ years & $\begin{array}{l}0.049 \\
(0.002)\end{array}$ & $\begin{array}{l}0.015^{*} \\
(0.001)\end{array}$ & $\begin{array}{l}0.063 \\
(0.002)\end{array}$ & $\begin{array}{l}0.018^{*} \\
(0.001)\end{array}$ \\
\hline African & $\begin{array}{l}0.644 \\
(0.010)\end{array}$ & $\begin{array}{l}0.885^{*} \\
(0.007)\end{array}$ & $\begin{array}{l}0.663 \\
(0.010)\end{array}$ & $\begin{array}{l}0.898^{*} \\
(0.005)\end{array}$ \\
\hline White & $\begin{array}{l}0.198 \\
(0.009)\end{array}$ & $\begin{array}{l}0.022^{*} \\
(0.002)\end{array}$ & $\begin{array}{l}0.183 \\
(0.009)\end{array}$ & $\begin{array}{l}0.022^{*} \\
(0.002)\end{array}$ \\
\hline Indian & $\begin{array}{l}0.037 \\
(0.004)\end{array}$ & $\begin{array}{l}0.013^{*} \\
(0.002)\end{array}$ & $\begin{array}{l}0.038 \\
(0.004)\end{array}$ & $\begin{array}{l}0.013^{*} \\
(0.002)\end{array}$ \\
\hline Coloured & $\begin{array}{l}0.121 \\
(0.006)\end{array}$ & $\begin{array}{l}0.080^{* *} \\
(0.006)\end{array}$ & $\begin{array}{l}0.115 \\
(0.006)\end{array}$ & $\begin{array}{l}0.667^{*} \\
(0.005)\end{array}$ \\
\hline Female & $\begin{array}{l}0.389 \\
(0.004)\end{array}$ & $\begin{array}{l}0.566^{*} \\
(0.005)\end{array}$ & $\begin{array}{l}0.417 \\
(0.004)\end{array}$ & $\begin{array}{l}0.571^{*} \\
(0.005)\end{array}$ \\
\hline Married & $\begin{array}{l}0.578 \\
(0.001)\end{array}$ & $\begin{array}{l}0.264^{*} \\
(0.006)\end{array}$ & $\begin{array}{l}0.583 \\
(0.006)\end{array}$ & $\begin{array}{l}0.292^{*} \\
(0.006)\end{array}$ \\
\hline Household characteristics & & & & \\
\hline Household size & $\begin{array}{l}4.744 \\
(0.042)\end{array}$ & $\begin{array}{l}6.403^{*} \\
(0.056)\end{array}$ & $\begin{array}{l}3.979 \\
(0.038)\end{array}$ & $\begin{array}{l}5.755^{*} \\
(0.056)\end{array}$ \\
\hline Receipt of social transfer & $\begin{array}{l}0.1065 \\
(0.004)\end{array}$ & $\begin{array}{l}0.250^{*} \\
(0.009)\end{array}$ & $\begin{array}{l}0.209 \\
(0.005)\end{array}$ & $\begin{array}{l}0.485^{*} \\
(0.008)\end{array}$ \\
\hline Urban & $\begin{array}{l}0.655 \\
(0.010)\end{array}$ & $\begin{array}{l}0.530^{*} \\
(0.015)\end{array}$ & $\begin{array}{l}0.682 \\
(0.007)\end{array}$ & $\begin{array}{l}0.545^{*} \\
(0.008)\end{array}$ \\
\hline $\mathrm{N}$ & 9593566 & 3995393 & 11322154 & 8356654 \\
\hline
\end{tabular}

Source: OHS 1995 and LFS 2003: 2

Notes: $\quad$ 1. The data are weighted using the population weights released by Stats SA in September 2005. 2. Standard errors in parentheses. * Significant at the 1 per cent level ${ }^{* *}$ Significant at the 5 per cent level ${ }^{* * *}$ Significant at the 10 per cent level. 
Table 13: Probability of Unemployment (searching and non-searching) Disaggregated by Race, 1995 and 2003

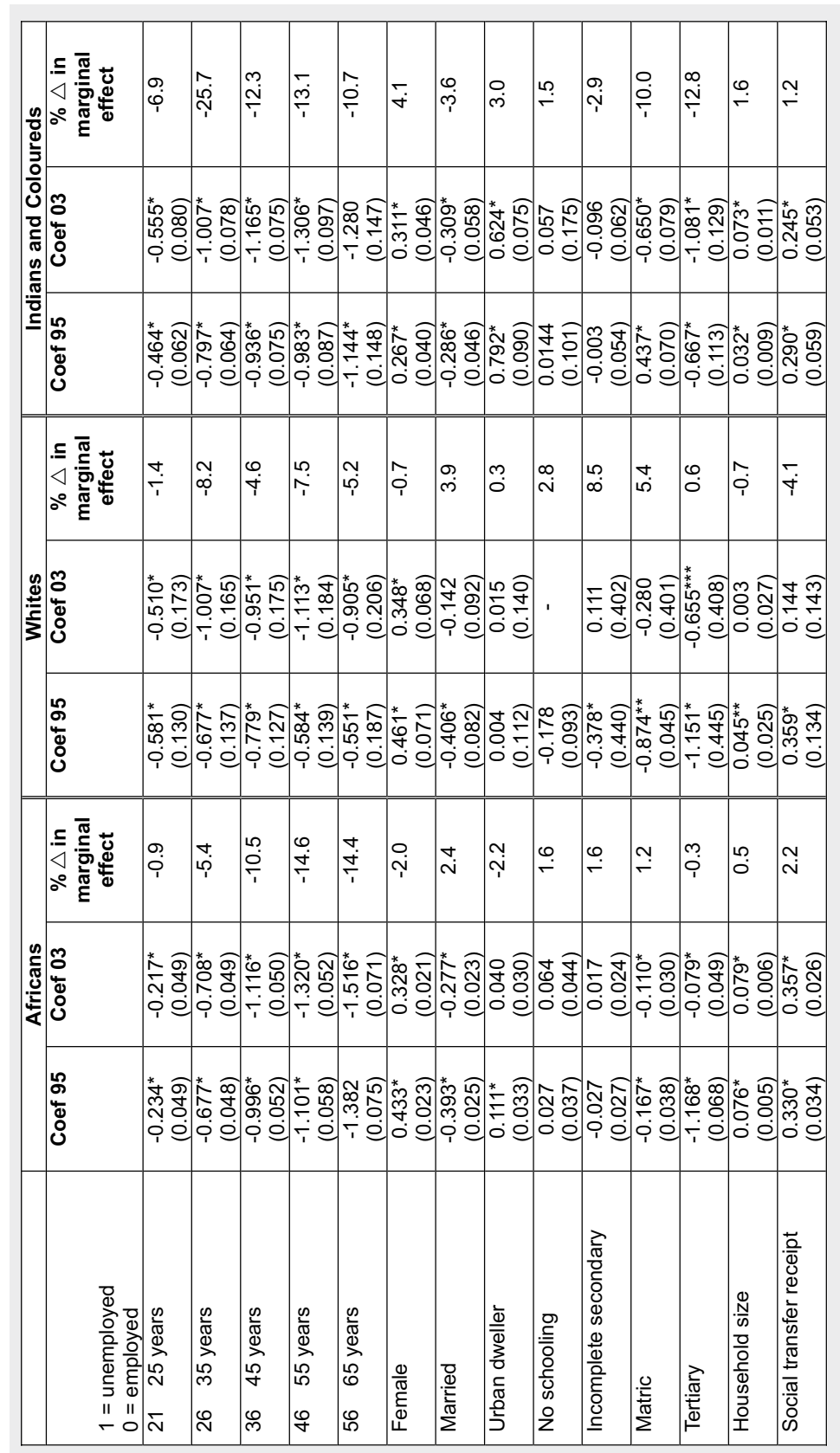

Source: OHS 1995 and LFS 2003: 2

Notes: Omitted categories are individuals aged 16 to 20 years, with primary school education, living in rural areas. The regression also included 9 provincial dummy variables not reported here. Standard errors are in parentheses. * Significant at the 1 per cent level ** Significant at the 5 per cent level *** Significant at the 10 per cent level. 
Table 14: Probability of Unemployment (searching and non-searching) amongst Males Disaggregated by Race, 1995 and 2003

\begin{tabular}{|c|c|c|c|c|c|c|c|c|c|c|c|c|c|}
\hline 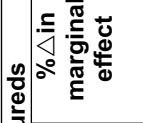 & مْ & $\underset{+}{\stackrel{T}{\leftarrow}}$ & $\underset{\substack{\infty \\
\infty \\
\infty}}{ }$ & $\underset{i}{\infty}$ & 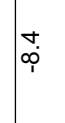 & $\frac{m}{1}$ & $\stackrel{\leftrightarrow}{\circ}$ & $\begin{array}{l}\infty \\
\dot{p} \\
\dot{p}\end{array}$ & pִ & 舅 & $\frac{n}{0}$ & $\stackrel{\infty}{\infty}$ & مִ \\
\hline 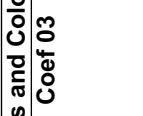 & 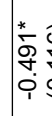 & & $\begin{array}{l}* \\
\infty \\
\infty \\
\infty \\
0 \\
i\end{array}$ & & 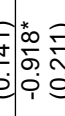 & 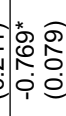 & 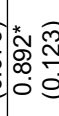 & : & 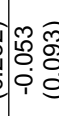 & : & : & {$\left[\begin{array}{ll}* & 0 \\
0 & 0 \\
0 & 0 \\
0 & 0\end{array}\right.$} & {$\left[\begin{array}{ll}* & 0 \\
2 & 0 \\
2 & 0 \\
0 & 0\end{array}\right.$} \\
\hline 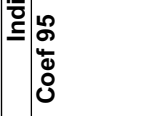 & 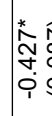 & & $\begin{array}{l}* \\
0 \\
\infty \\
0 \\
0 \\
i \\
i\end{array}$ & 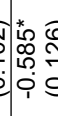 & 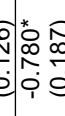 & $\begin{cases}* & 0 \\
0 & 0 \\
0 & 0 \\
0 & 0 \\
1 & 0\end{cases}$ & {$\left[\begin{array}{lll}* & \sqrt{2} \\
\infty & 0 \\
0 & 0 & 0 \\
0 & 0\end{array}\right.$} & $\hat{y}$ & 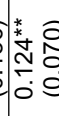 & : & 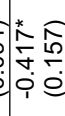 & & $\mid \begin{array}{lll}* & 0 \\
0 & 0 \\
0 & 0 \\
0 & 0 \\
0 & 0\end{array}$ \\
\hline 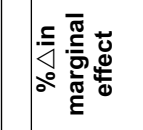 & 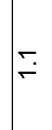 & $\stackrel{m}{\tilde{y}}$ & $\stackrel{\uparrow}{\bar{T}}$ & 我 & $\underset{\sim}{\stackrel{\sim}{\sim}}$ & $\stackrel{m}{\rightarrow}$ & $\hat{N}$ & 1 & $\underset{+}{\stackrel{f}{+}}$ & $\stackrel{\circ}{\text { N }}$ & $\frac{m}{T}$ & $\bar{o}$ & $\stackrel{\infty}{\bar{T}}$ \\
\hline 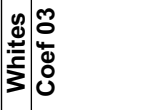 & 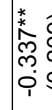 & & יa & 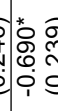 & & $\mid \begin{array}{ll}* \\
0\end{array}$ & 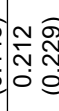 & & 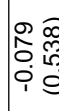 & $\hat{:}$ & 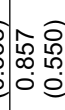 & & {$\left[\begin{array}{ll}\infty & 0 \\
0 & 0 \\
& 0 \\
0 & 0\end{array}\right.$} \\
\hline 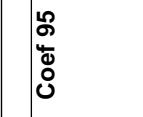 & 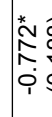 & 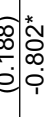 & 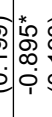 & $\hat{a}$ & 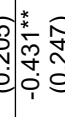 & 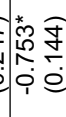 & $\frac{0}{0}$ & 竞 & $\mid \begin{array}{l}n \\
0 \\
0 \\
0 \\
0 \\
0 \\
0\end{array}$ & 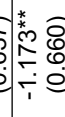 & 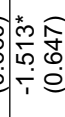 & & 空 \\
\hline 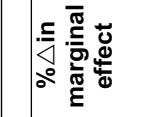 & : & ف잉 & $\frac{\rho}{T}$ & 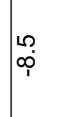 & $\overbrace{\substack{0 \\
\infty}}$ & קهి & O̊. & N & $\stackrel{\circ}{\circ}$ & $\stackrel{\overbrace{}}{\bar{T}}$ & $\underset{\sim}{\sim}$ & $\hat{o}$ & \\
\hline 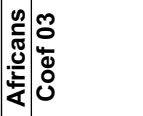 & $\begin{array}{l}* \\
0 \\
0 \\
0 \\
0 \\
i \\
1 \\
1\end{array}$ & & $\begin{array}{l}n \\
\\
\vdots \\
\vdots\end{array}$ & $\mid \begin{array}{ll}* \\
0 \\
0 & 15 \\
0 & 0 \\
0 & 0 \\
1 & 0\end{array}$ & 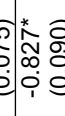 & 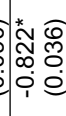 & & $\mid \begin{array}{ll}0 & \\
0 & 0 \\
0 & 0 \\
0 & 0\end{array}$ & 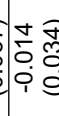 & 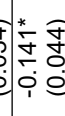 & $\begin{cases}* & \\
4 & \\
0 & 0 \\
0 & 0 \\
1 & 0\end{cases}$ & & 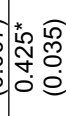 \\
\hline 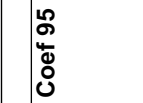 & 苂 & 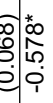 & ن & 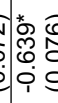 & 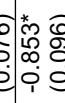 & 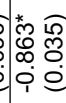 & : & the & 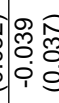 & 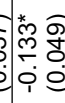 & 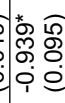 & & $\left(\begin{array}{cc}* & \\
0 & \\
0 & 0 \\
0 & 0 \\
0 & 0\end{array}\right.$ \\
\hline 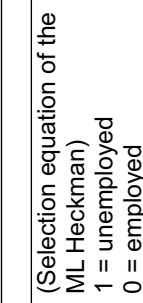 & & 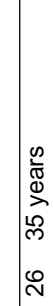 & 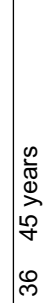 & 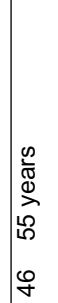 & 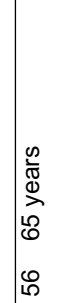 & 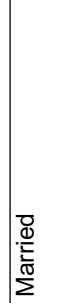 & 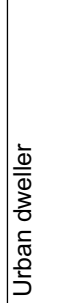 & 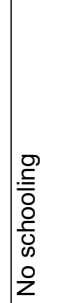 & 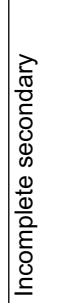 & 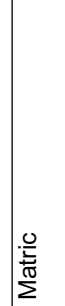 & 胥 & 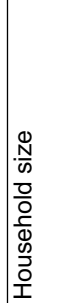 & 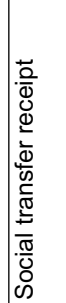 \\
\hline
\end{tabular}

Source: OHS 1995 and LFS 2003: 2

Notes: Omitted categories are individuals aged 16 to 20 years, with primary school education, living in rural areas. The regression also included 9 provincial dummy variables not reported here. Standard errors are in parentheses. * Significant at the 1 per cent level ${ }^{* *}$ Significant at the 5 per cent level ${ }^{* * *}$ Significant at the 10 per cent level. 
Table 15: Probability of Unemployment (searching and non-searching) amongst Females Disaggregated by Race, 1995 and 2003

\begin{tabular}{|c|c|c|c|c|c|c|c|c|c|c|c|c|c|c|}
\hline$\underset{\mathbf{d}}{\mathbf{d}}$ & 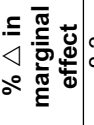 & m. & 我 & $\begin{array}{l}0 \\
\dot{T} \\
\dot{T}\end{array}$ & مُ & $\begin{array}{l}0 \\
\stackrel{0}{1} \\
1\end{array}$ & 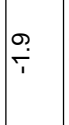 & ه্ & ف & $\frac{O}{\bar{T}}$ & $\stackrel{m}{m}$ & $\begin{array}{l}\infty \\
\stackrel{+}{T}\end{array}$ & $\stackrel{n}{\sim}$ & $\stackrel{\infty}{-}$ \\
\hline 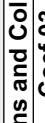 & 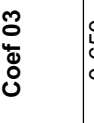 & 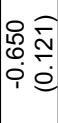 & $\mid$\begin{tabular}{ll}
$*$ & $\widehat{5}$ \\
0 & 0 \\
\hdashline & 0 \\
\hdashline & 0
\end{tabular} & $\begin{cases}* & 0 \\
0 & 0 \\
\hdashline & 0 \\
\hdashline & 0\end{cases}$ & 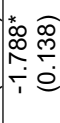 & 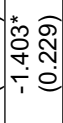 & $\mid \begin{array}{ll} & \\
0 & 0 \\
0 & 0 \\
0 & 0\end{array}$ & 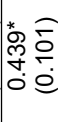 & 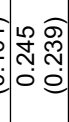 & $\mid \begin{array}{ll}0 & 0 \\
0 & 0 \\
0 & 0 \\
1 & 0\end{array}$ & 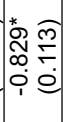 & 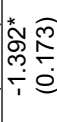 & $\begin{array}{ll}* & 0 \\
8 & 0 \\
0 & 0 \\
0 & 0\end{array}$ & 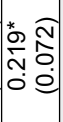 \\
\hline 흔 & $\begin{array}{l}\text { ๐̊ } \\
4 \\
0 \\
0\end{array}$ & $\begin{array}{ll}* & \widehat{\approx} \\
0 & 0 \\
0 & 0 \\
0 & 0 \\
1 & 0\end{array}$ & $\begin{array}{ll}* & \\
0 & \bar{g} \\
\infty & 0 \\
0 & 0 \\
0 & 0\end{array}$ & 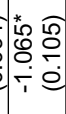 & 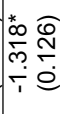 & 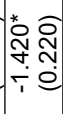 & 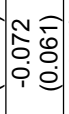 & 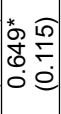 & 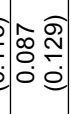 & {$\left[\begin{array}{ll}0 & 0 \\
0 & 0 \\
\hdashline & 0 \\
\hdashline & 0 \\
1 & 0\end{array}\right.$} & 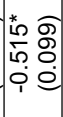 & 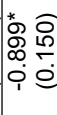 & 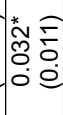 & 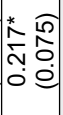 \\
\hline & 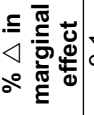 & कृ. & $\begin{array}{l}\infty \\
\varphi \\
\varphi\end{array}$ & p. & $\frac{\mathscr{C}}{\underset{T}{\tau}}$ & $\underset{T}{\stackrel{T}{~}}$ & की & m. & & 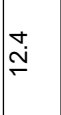 & $\stackrel{\circ}{\circ}$ & $\stackrel{\sim}{\sim}$ & $\stackrel{\varphi}{\sim}$ & $\begin{array}{l}\stackrel{0}{m} \\
\stackrel{\Gamma}{T}\end{array}$ \\
\hline $\begin{array}{l}\boldsymbol{g} \\
\mathbf{d} \\
\mathbf{z} \\
\mathbf{z}\end{array}$ & 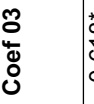 & 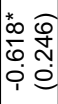 & 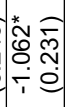 & 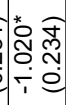 & 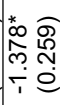 & 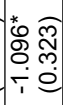 & $\mid \begin{array}{ll}0 & 0 \\
0 & 0 \\
0 & c \\
0 & 0\end{array}$ & 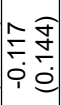 & & $\begin{array}{lll}m & \bar{\sigma} \\
& \overline{0} \\
0 & 0 & 0\end{array}$ & 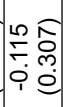 & 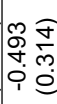 & {$\left[\begin{array}{ll}\infty & \widetilde{m} \\
0 & 0 \\
0 & 0 \\
0 & 0\end{array}\right.$} & 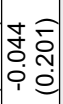 \\
\hline & $\begin{array}{l}\text { ก̊ } \\
4 \\
0 \\
0\end{array}$ & 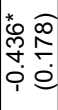 & 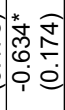 & {$\left[\begin{array}{ll}* & - \\
0 & \mathbb{N} \\
0 & - \\
0 & 0\end{array}\right.$} & 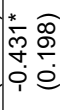 & $\begin{array}{ll}* & \\
1 & 0 \\
0 & 0 \\
0 & 0 \\
0 & 0 \\
& 0\end{array}$ & $\mid$\begin{tabular}{ll}
$*$ & 0 \\
$N$ & 0 \\
\hdashline & 0 \\
& 0 \\
1 & 0
\end{tabular} & 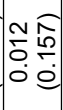 & & 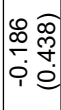 & $\begin{array}{ll}\overline{0} & 0 \\
0 & 9 \\
0 & 9 \\
0 & 0 \\
1 & 0\end{array}$ & 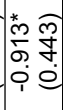 & {$\left[\begin{array}{ll}* & 0 \\
\delta & 0 \\
0 & 0 \\
0 & 0\end{array}\right.$} & 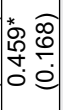 \\
\hline & 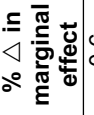 & ب. & $\stackrel{\text { }}{\text { ஸे }}$ & $\begin{array}{l}0 \\
\infty \\
1\end{array}$ & $\underset{\sim}{\stackrel{m}{T}}$ & $\begin{array}{l}0 \\
\stackrel{0}{\circ} \\
\frac{1}{1}\end{array}$ & $\check{f}$ & $\frac{\sigma^{\circ}}{\bar{r}}$ & \begin{tabular}{l}
$m$ \\
mo \\
\hdashline
\end{tabular} & $\stackrel{p}{\longrightarrow}$ & $\stackrel{\sim}{n}$ & $\begin{array}{l}0 \\
\dot{\sigma}\end{array}$ & $\stackrel{\varphi}{\circ}$ & $\stackrel{n}{\sim}$ \\
\hline 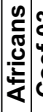 & 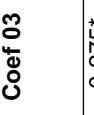 & 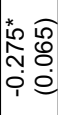 & {$\left[\begin{array}{ll}* & \overline{0} \\
0 & \overline{8} \\
0 & 0 \\
0 & 0 \\
1 & 0\end{array}\right.$} & 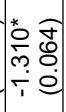 & $\mid$\begin{tabular}{ll}
$*$ & - \\
0 & 0 \\
0 & 0 \\
$-i$ & 0 \\
\hdashline & 0
\end{tabular} & 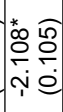 & $\mid \begin{array}{ll}* & 0 \\
c & 0 \\
0 & 0 \\
0 & 0 \\
0 & 0\end{array}$ & 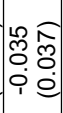 & 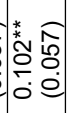 & $\begin{array}{ll}0 & 0 \\
0 & 0 \\
0 & 0 \\
0 & 0 \\
0\end{array}$ & 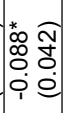 & $\mid \begin{array}{ll}* & \\
0 & \overline{0} \\
\infty & 0 \\
0 & 0\end{array}$ & $\mid \begin{array}{ll}* & \\
N & 8 \\
0 & 0 \\
0 & 0\end{array}$ & 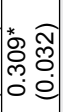 \\
\hline & 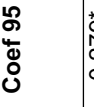 & $\begin{array}{ll}* & 0 \\
& 0 \\
\text { N } & 0 \\
0 & 0 \\
1 & 0\end{array}$ & $\mid \begin{array}{cc}* & \widehat{y} \\
& 0 \\
0 & 0 \\
0 & 0 \\
1 & 0\end{array}$ & $\mid$\begin{tabular}{ll}
0 & - \\
\hdashline & 0 \\
\hdashline & 0 \\
\hdashline & 0
\end{tabular} & 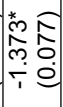 & 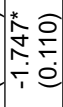 & {$\left[\begin{array}{ll}0 & 0 \\
0 & 0 \\
0 & 0 \\
0 & 0 \\
1 & 0\end{array}\right.$} & $\mid \begin{array}{ll} & \widehat{9} \\
0 & 0 \\
0 & 0 \\
0 & 0 \\
1 & 0\end{array}$ & {$\left[\begin{array}{cc}* & 0 \\
\stackrel{\infty}{*} & 0 \\
\hdashline & 0 \\
0 & 0\end{array}\right.$} & $\begin{array}{ll}1 & 0 \\
0 & 0 \\
0 & 0 \\
0 & 0\end{array}$ & 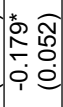 & 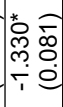 & 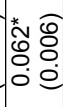 & 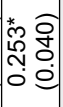 \\
\hline & 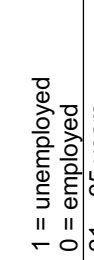 & 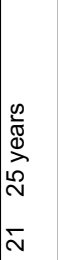 & 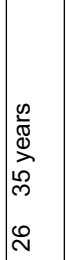 & 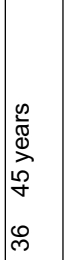 & 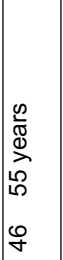 & 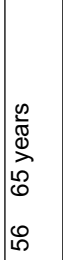 & . & 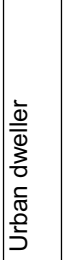 & 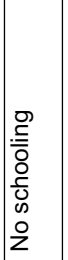 & 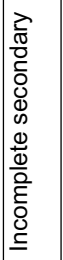 & $\mid \frac{0}{\frac{0}{E}}$ & 胥 & 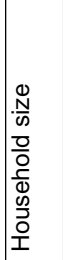 & 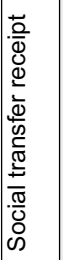 \\
\hline
\end{tabular}

Source: OHS 1995 and LFS 2003: 2

Notes: Omitted categories individuals aged 16 to 20 years, with primary school education, living in rural areas. The regression also included 9 provincial dummy variables not reported here. Standard errors are in parentheses. * Significant at the 1 per cent level ** Significant at the 5 per cent level ${ }^{* * *}$ Significant at the 10 per cent level. 
Table 16: Change in Employment in South Africa, 1995 and 2003

\begin{tabular}{|c|c|c|c|c|c|c|}
\hline & \multicolumn{2}{|c|}{ Absolute number } & \multicolumn{2}{|c|}{ Changes (03-95) } & \multicolumn{2}{|c|}{ Share of employment } \\
\hline & 1995 & 2003 & $\begin{array}{l}\text { Absolute } \\
\text { change }\end{array}$ & $\%$ change & 1995 & 2003 \\
\hline \multicolumn{7}{|l|}{ All sectors } \\
\hline Skilled & 827761 & 1356200 & 528439 & 63.8 & 0.09 & 0.12 \\
\hline semi-skilled & 5628133 & 6587077 & 958944 & 17.0 & 0.60 & 0.58 \\
\hline Unskilled & 2945622 & 3411382 & 465760 & 15.8 & 0.31 & 0.30 \\
\hline \multicolumn{7}{|l|}{ Agriculture } \\
\hline Skilled & 7347 & 55169 & 47822 & 650.9 & 0.01 & 0.05 \\
\hline semi-skilled & 276634 & 506694 & 230060 & 83.2 & 0.22 & 0.42 \\
\hline Unskilled & 957613 & 644437 & -313176 & -32.7 & 0.77 & 0.53 \\
\hline \multicolumn{7}{|l|}{ Mining } \\
\hline Skilled & 16093 & 24439 & 8346 & 51.9 & 0.04 & 0.04 \\
\hline semi-skilled & 346065 & 465469 & 119404 & 34.5 & 0.78 & 0.84 \\
\hline Unskilled & 83895 & 62248 & -21647 & -25.8 & 0.19 & 0.11 \\
\hline \multicolumn{7}{|c|}{ Manufacturing } \\
\hline Skilled & 88406 & 143187 & 54781 & 62.0 & 0.06 & 0.09 \\
\hline semi-skilled & 1075096 & 1170196 & 95100 & 8.8 & 0.74 & 0.76 \\
\hline Unskilled & 280600 & 231975 & -48625 & -17.3 & 0.19 & 0.15 \\
\hline \multicolumn{7}{|l|}{ Utilities } \\
\hline Skilled & 4899 & 15401 & 10502 & 214.4 & 0.06 & 0.17 \\
\hline semi-skilled & 68547 & 63670 & -4877 & -7.1 & 0.81 & 0.70 \\
\hline Unskilled & 11597 & 11999 & 402 & 3.5 & 0.14 & 0.13 \\
\hline \multicolumn{7}{|l|}{ Construction } \\
\hline Skilled & 27897 & 47396 & 19499 & 69.9 & 0.06 & 0.07 \\
\hline semi-skilled & 332792 & 456893 & 124101 & 37.3 & 0.74 & 0.69 \\
\hline Unskilled & 86532 & 153874 & 67342 & 77.8 & 0.19 & 0.23 \\
\hline \multicolumn{7}{|l|}{ Retail } \\
\hline Skilled & 231707 & 249483 & 17776 & 7.7 & 0.14 & 0.10 \\
\hline semi-skilled & 1120563 & 1397804 & 277241 & 24.7 & 0.67 & 0.58 \\
\hline Unskilled & 328272 & 775686 & 447414 & 136.3 & 0.20 & 0.32 \\
\hline \multicolumn{7}{|l|}{ Transport } \\
\hline Skilled & 72030 & 100295 & 28265 & 39.2 & 0.15 & 0.19 \\
\hline semi-skilled & 353454 & 363953 & 10499 & 3.0 & 0.74 & 0.68 \\
\hline Unskilled & 54529 & 69820 & 15291 & 28.0 & 0.11 & 0.13 \\
\hline \multicolumn{7}{|l|}{ Finance } \\
\hline Skilled & 99624 & 306210 & 206586 & 207.4 & 0.17 & 0.28 \\
\hline semi-skilled & 455340 & 675948 & 220608 & 48.4 & 0.77 & 0.62 \\
\hline Unskilled & 36368 & 112770 & 76402 & 210.1 & 0.06 & 0.10 \\
\hline \multicolumn{7}{|c|}{ Community services } \\
\hline Skilled & 279274 & 412866 & 133592 & 47.8 & 0.13 & 0.19 \\
\hline semi-skilled & 1578437 & 1480529 & -97908 & -6.2 & 0.73 & 0.68 \\
\hline Unskilled & 317395 & 281300 & -36095 & -11.4 & 0.15 & 0.13 \\
\hline \multicolumn{7}{|c|}{ Private households } \\
\hline Skilled & 484 & 0 & -484 & -100.0 & 0.00 & 0.00 \\
\hline semi-skilled & 21205 & 5044 & -16161 & -76.2 & 0.03 & 0.00 \\
\hline Unskilled & 788822 & 1067010 & -278188 & 35.3 & 0.97 & 1.00 \\
\hline
\end{tabular}

Source: OHS 1995 and LFS 2003: 2 
Table 17: Change in Employment Excluding Self-Employment in South Africa, 1995 and 2003

\begin{tabular}{|c|c|c|c|c|c|c|}
\hline & \multicolumn{2}{|c|}{ Absolute number } & \multicolumn{2}{|c|}{ Changes (03-95) } & \multicolumn{2}{|c|}{ Share of employment } \\
\hline & 1995 & 2003 & $\begin{array}{l}\text { Absolute } \\
\text { change }\end{array}$ & $\%$ change & 1995 & 2003 \\
\hline \multicolumn{7}{|l|}{ All sectors } \\
\hline Skilled & 566297 & 924072 & 357775 & 63.18 & 0.07 & 0.10 \\
\hline semi-skilled & 5319363 & 5540959 & 221596 & 4.17 & 0.61 & 0.59 \\
\hline Unskilled & 2831497 & 2862618 & 31121 & 1.10 & 0.32 & 0.31 \\
\hline \multicolumn{7}{|l|}{ Agriculture } \\
\hline Skilled & 5853 & 14412 & 8559 & 146.23 & 0.01 & 0.02 \\
\hline semi-skilled & 212776 & 225033 & 12257 & 5.76 & 0.18 & 0.25 \\
\hline Unskilled & 951161 & 641190 & -309971 & -32.59 & 0.81 & 0.73 \\
\hline \multicolumn{7}{|l|}{ Mining } \\
\hline Skilled & 15754 & 23598 & 7844 & 49.79 & 0.03 & 0.04 \\
\hline semi-skilled & 345939 & 465203 & 119264 & 34.48 & 0.78 & 0.85 \\
\hline Unskilled & 83895 & 61922 & -21973 & -26.19 & 0.19 & 0.11 \\
\hline \multicolumn{7}{|l|}{ Manufacturing } \\
\hline Skilled & 73958 & 108690 & 34732 & 46.96 & 0.06 & 0.08 \\
\hline semi-skilled & 1014978 & 1021377 & 6399 & 0.63 & 0.74 & 0.75 \\
\hline Unskilled & 279137 & 224099 & -55038 & -19.71 & 0.20 & 0.17 \\
\hline \multicolumn{7}{|l|}{ Utilities } \\
\hline Skilled & 4899 & 15401 & 10502 & 2.14 & 0.06 & 0.17 \\
\hline semi-skilled & 68380 & 62740 & -5640 & 8.25 & 0.80 & 0.70 \\
\hline Unskilled & 11597 & 11990 & 393 & 3.39 & 0.14 & 0.13 \\
\hline \multicolumn{7}{|l|}{ Construction } \\
\hline Skilled & 13078 & 20912 & 7834 & 59.90 & 0.03 & 0.04 \\
\hline semi-skilled & 276615 & 328291 & 51676 & 18.68 & 0.74 & 0.67 \\
\hline Unskilled & 86039 & 144747 & 58708 & 68.23 & 0.23 & 0.29 \\
\hline \multicolumn{7}{|l|}{ Retail } \\
\hline Skilled & 90358 & 119341 & 28983 & 32.08 & 0.06 & 0.08 \\
\hline semi-skilled & 1056512 & 1110035 & 53523 & 5.07 & 0.77 & 0.74 \\
\hline Unskilled & 229051 & 265037 & 35986 & 15.71 & 0.17 & 0.18 \\
\hline \multicolumn{7}{|l|}{ Transport } \\
\hline Skilled & 27646 & 52615 & 24969 & 90.32 & 0.06 & 0.12 \\
\hline semi-skilled & 351412 & 339699 & 11713 & 3.33 & 0.81 & 0.74 \\
\hline Unskilled & 54529 & 64986 & 10457 & 19.18 & 0.13 & 0.14 \\
\hline \multicolumn{7}{|l|}{ Finance } \\
\hline Skilled & 72111 & 210097 & 137986 & 191.35 & 0.13 & 0.22 \\
\hline semi-skilled & 432555 & 614946 & 182391 & 42.17 & 0.80 & 0.66 \\
\hline Unskilled & 36368 & 109487 & 73119 & 201.05 & 0.07 & 0.12 \\
\hline \multicolumn{7}{|l|}{ Community services } \\
\hline Skilled & 262639 & 357252 & 94613 & 36.02 & 0.12 & 0.18 \\
\hline semi-skilled & 1540808 & 1369430 & -171378 & -11.12 & 0.73 & 0.68 \\
\hline Unskilled & 313323 & 273190 & -40133 & -12.80 & 0.15 & 0.14 \\
\hline \multicolumn{7}{|l|}{ Private households } \\
\hline Skilled & 0 & 0 & 0 & - & 0.00 & 0.00 \\
\hline semi-skilled & 19387 & 3328 & -16059 & -82.87 & 0.02 & 0.00 \\
\hline Unskilled & 786396 & 1065697 & 279301 & 35.52 & 0.98 & 1.00 \\
\hline
\end{tabular}

Source: OHS 1995 and LFS 2003: 2

Note: In the 1995 OHS, domestic workers were post-coded by Stats SA as self-employed whereas in all subsequent surveys they are considered to be working for someone else. For the purpose of comparability, domestic workers in 1995 have been reclassified as "employees" and are, therefore, included in estimates of private household employment. 


\section{References}

Bhorat, H. (2004) 'The Development challenge in post-apartheid South African education'. In: L. Chisholm (ed.) Changing education and social change in post-apartheid South Africa. Cape Town: HSRC Press and London: Zed Books

Bhorat, H. and Hodge, J. (1999) 'Decomposing shifts in labour demand in South Africa'. The South African Journal of Economics 67(3): 348 - 380.

Bhorat, H. and Leibbrandt, M. (2001) 'Correlates of vulnerability in the South African labour market'. In: Bhorat, H., Leibbrandt M, Maziya, M., van der Berg, S., Woolard, I. Fighting poverty. Labour markets and inequality in South Africa. Cape Town: UCT Press.

Casale, D. and Posel, D. (2006) 'A review of the labour market in KwaZulu-Natal, 1995 2003'. Report prepared for the Department of Economic Development, KwaZulu-Natal.

Cassim, R. (2006) 'Reflections on South Africa's first wave of economic reforms'. In: V. Padayachee (ed.) The development decade? Economic and social change in South Africa, 1994-2004. Cape Town: HSRC Press.

Chandra, V. and Nganou, J. (2001) 'Obstacles to Formal Employment Creation in South Africa: Evidence from Recent Firm Surveys'. Paper presented to the DPRU Conference, Johannesburg.

Cichello, P., Fields, G.S. and Leibbrandt, M. (2003) 'Earnings and employment dynamics for Africans in post-Apartheid South Africa: A panel study of KwaZuluNatal'. Development Policy Research Unit Working Paper, no. 77.

Department of Education (2005) 'Education Statistics in South Africa at a glance in 2004'. Pretoria.

Devey, R., Valodia, I. and Velia, M. (2005) 'Constraints to Growth and Employment: Evidence from the Greater Durban Metropolitan Area'. Research Report No 64, School of Development Studies.

Hosking, S. (2001) 'Rates of return to education in South Africa, 1960 - 1996'. Paper presented at the DPRU conference, 2001. 
Hoogeveen and Özler (2004) 'Not separate, not equal: Poverty and inequality in postapartheid South Africa'. World Bank, Working Paper.

Kingdon, G. and Knight, J. (2005) 'Unemployment in South Africa: Causes, Problems and Policies'. Paper presented at the conference, "The South African Economy Under Democracy: A 10 Year Review of Economic Policies", Stellenbosch.

Moleke, P. (2006) 'Finding Work. Employment Experiences of South African Graduates'. HSRC Research Monograph.

Naidoo, K. (2006) 'Operationalising South Africa's move from macro-economic stability to micro-economic reform'. In: V. Padayachee (ed.) The development decade? Economic and social change in South Africa, 1994 - 2004. Cape Town: HSRC Press.

Posel, D. and Casale, D. (2001) 'Gender Aggregates: Women Subsistence Farmers Affect the Unemployment Count'. Agenda, 49: 82 - 88.

Poswell, L. (2002) 'The Post-Apartheid South African Labour Market: A Status Report'. Development Policy Researh Unit, University of Cape Town.

Schultz, T.P., and Mwabu, G. (1998) 'Labour unions and the distribution of wages and employment in South Africa'. Industrial and Labour Relations, 51(4).

Simkins, C. (2001) 'South Africa's stock of human capital'. Econometric Research Southern Africa, Working Paper, Department of Economics, University of Witwatersrand.

Statistics South Africa (2005) 'Labour Force Survey, September 2000 to March 2005: Historical Series of Revised Estimates'. Statistical Release P0210, Embargoed until September 2005.

Umalusi (2004) 'Investigation into the senior certificate examination: summary report on the evaluation of the senior certificate examination', August 2004, Accessed at: www.umalusi.org.za/int/ur/researchdocuments/umalusi\%205\%research.pdf on $20 / 08 / 2005$.

Van der Berg, S. and Burger, R. (2003) 'Education and socio-economic differentials: A study of school performance in the Western Cape'. Development Policy Research Unit Working Paper, no. 73. 